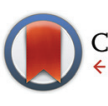

CrossMark \& click for updates

Cite this: Dalton Trans., 2015, 44 9756

Received 13th March 2015 Accepted 15th April 2015

DOI: $10.1039 / c 5 d t 01022 \mathrm{e}$ www.rsc.org/dalton

\title{
Synthesis of chelating diamido Sn(Iv) compounds from oxidation of Sn(II) and directly from Sn(IV) precursors $\uparrow$
}

\begin{abstract}
S. M. Mansell, ${ }^{* a}$ C. A. Russell ${ }^{* b}$ and D. F. Wass ${ }^{* b}$
Three dimethyltindiamides containing chelating diamide ligands were synthesised from the reaction of the dilithiated diamine and $\mathrm{Me}_{2} \mathrm{SnCl}_{2} ;\left[\mathrm{SnMe}_{2}\left(\mathrm{~L}_{1}\right)\right] \mathbf{1}\left(\mathrm{L}_{1}=\kappa^{2}-\mathrm{N}(\operatorname{Dipp}) \mathrm{C}_{2} \mathrm{H}_{4} \mathrm{~N}(\operatorname{Dipp})\right)$, [SnMe $\left.\left(\mathrm{L}_{2}\right)\right] 2\left(\mathrm{~L}_{2}=\right.$ $\kappa^{2}-\mathrm{N}($ Dipp $) \mathrm{C}_{3} \mathrm{H}_{6} \mathrm{~N}\left(\right.$ Dipp)) and $\left[\mathrm{SnMe}_{2}\left(\mathrm{~L}_{3}\right)\right] 3\left(\mathrm{~L}_{3}=\kappa^{2}-\mathrm{N}(\operatorname{Dipp}) \mathrm{SiPh}_{2} \mathrm{~N}(\operatorname{Dipp})\right)$, Dipp = 2,6- ${ }^{\mathrm{i}} \mathrm{Pr}_{2} \mathrm{C}_{6} \mathrm{H}_{3}$. Reaction of $\left(\mathrm{L}_{2}\right) \mathrm{H}_{2}$ with $\mathrm{SnCl}_{4}$ and $\mathrm{NEt}_{3}$ led to the formation of the diamidotin dichloride $\left[\mathrm{SnCl}_{2}\left(\mathrm{~L}_{2}\right)\right] \mathbf{4}$ whereas reaction of $\left(\mathrm{L}_{1}\right) \mathrm{H}_{2}$ with $\mathrm{SnCl}_{4}$ and $\mathrm{NEt}_{3}$, or $\left[\mathrm{Sn}\left(\mathrm{L}_{1}\right)\right]$ with $\mathrm{SnCl}_{4}$, led to the exclusive formation of the amidotin trichloride $\left[\mathrm{SnCl}_{3}\left\{\kappa^{2}-\operatorname{DippN}(\mathrm{H}) \mathrm{C}_{2} \mathrm{H}_{4} \mathrm{~N}(\mathrm{Dipp})\right\}\right]$ 5. Reactions of $\left[\mathrm{Sn}\left(\mathrm{L}_{1}\right)\right]$ with sulfur and selenium formed $\left[\left\{S n\left(L_{1}\right)(\mu-E)\right\}_{2}\right](E=S 10$ and Se 11). Mel reacted with $N$-heterocyclic stannylenes to generate the $S n(I V)$ addition products $\left[S n(M e) I\left(L_{1}\right)\right]$ 12, [Sn(Me)I(L $\left.\left.L_{2}\right)\right]$ 13, $\left[S n(M e) I\left(L_{3}\right)\right] 14$ and $\left[S n(M e) I\left(L_{4}\right)\right] 15\left(L_{4}=\kappa^{3}-N(D i p p)-\right.$ $\left.\mathrm{C}_{2} \mathrm{H}_{4} \mathrm{OC}_{2} \mathrm{H}_{4} \mathrm{~N}(\mathrm{Dipp})\right)$, and subsequent reaction with $\mathrm{AgOTf}\left(\mathrm{OTf}=\mathrm{OSO}_{2} \mathrm{CF}_{3}\right)$ generated the corresponding $\mathrm{Sn}(\mathrm{iv})$ triflates $\left[\mathrm{Sn}(\mathrm{Me}) \mathrm{OTf}\left(\mathrm{L}_{1}\right)\right]$ 16, [Sn(Me)OTf( $\left.\left.\mathrm{L}_{2}\right)\right] 17$ and $\left[\mathrm{Sn}(\mathrm{Me}) \mathrm{OTf}\left(\mathrm{L}_{4}\right)\right] 19$ with [Sn(Me)OTf $\left.\left(\mathrm{L}_{3}\right)\right] 18$ formed only as a mixture with unidentified by-products. All of the compounds were characterised by single crystal $\mathrm{X}$-ray diffraction.
\end{abstract}

\section{Introduction}

The synthesis and reactivity of heteroleptic amidotin-halides are much less studied than the corresponding amidotinalkyls despite their obvious potential for further chemical transformations both via salt metathesis reactions and through protonolysis of the tin-amide bond. Previously Lappert and co-workers demonstrated the synthesis of the chloride-bridged dimeric $\mathrm{Sn}$ (II) species $\left[\mathrm{Sn}\left\{\mathrm{N}\left(\mathrm{SiMe}_{3}\right)_{2}\right\}(\mu-\mathrm{Cl})\right]_{2}$ and $\left[\mathrm{Sn}\left\{\mathrm{N}\left(\mathrm{CMe}_{2} \mathrm{CH}_{2}\right)_{2} \mathrm{CH}_{2}\right\}(\mu-\mathrm{Cl})\right]_{2}$ from the redistribution of acyclic amido-stannylenes with $\mathrm{SnCl}_{2}$ and these have proved to be useful starting materials. ${ }^{1,2}$ Additionally, Wrackmeyer and co-workers studied the oxidation of the stannylenes $\left[\mathrm{Sn}\left\{\mathrm{N}\left(\mathrm{SiMe}_{3}\right)_{2}\right\}_{2}\right]$ and $\left[\mathrm{Sn}\left(\kappa^{2}-\mathrm{N}-\right.\right.$ $\left.\left({ }^{t} \mathrm{Bu}\right) \mathrm{Si}_{2} \mathrm{Me}_{4} \mathrm{~N}\left({ }^{t} \mathrm{Bu}\right)\right]$ with $\mathrm{SnCl}_{4}$ by multinuclear NMR spectroscopy and found the reactions proceed with ease yielding tin(Iv) dichloride species. ${ }^{3}$ In a more direct synthesis, diamine ligand precursors can be reacted with $\mathrm{SnCl}_{4}$ and $\mathrm{NEt}_{3}$ to give the corresponding diamidotindichloride species in good

\footnotetext{
${ }^{a}$ Institute of Chemical Sciences, Heriot-Watt University, Edinburgh, EH14 4S, UK. E-mail: s.mansell@hw.ac.uk

${ }^{b}$ School of Chemistry, University of Bristol, Cantock's close, Bristol, BS8 1TS, UK. E-mail: chris.russell@bristol.ac.uk, duncan.wass@bristol.ac.uk

$\dagger$ Electronic supplementary information (ESI) available: A table containing additional crystallographic information and molecular structures of compounds 1-5 and 10-19. CCDC 1027507-1027522. For ESI and crystallographic data in CIF or other electronic format see DOI: 10.1039/c5dt01022e
}

yield. ${ }^{3}$ Molecular structures were determined by X-ray crystallography for the five-membered ring dichlorotin species $\left[\mathrm{SnCl}_{2}\left(\kappa^{2}-\mathrm{N}\left({ }^{t} \mathrm{Bu}\right) \mathrm{Si}_{2} \mathrm{Me}_{4} \mathrm{~N}\left({ }^{t} \mathrm{Bu}\right)\right]\right.$ and also the ferrocenophane $\left[\mathrm{SnCl}_{2}\left(\kappa^{2}-\mathrm{N}\left(\mathrm{SiMe}_{3}\right) \mathrm{C}_{5} \mathrm{H}_{4} \mathrm{FeC}_{5} \mathrm{H}_{4} \mathrm{~N}\left(\mathrm{SiMe}_{3}\right)\right]^{4} \quad\right.$ Two additional molecular structures of non-chelating diamidodichlorotin species are also known; $\left[\mathrm{SnCl}_{2}\left\{\mathrm{~N}\left(\mathrm{SiPhMe}_{2}\right)_{2}\right\}_{2}\right]$ and $\left[\mathrm{SnCl}_{2}-\right.$ $\left.\left\{\mathrm{N}\left(\mathrm{SiMe}_{2} \mathrm{NH}\right)_{2} \mathrm{SiMe}_{2}\right\}_{2}\right],{ }^{5}$ however, for such potentially useful starting materials, relatively little is known about their chemistry. Oxidation reactions of tin(II) compounds are now an extensively studied area. ${ }^{6}$ Lappert and co-workers explored the oxidative addition chemistry of a number of haloalkanes with both alkyl- and amido-stannylenes and found them to be free radical in nature with the first step consisting of the transfer of an electron to the substrate, followed by abstraction of the halide to leave the tin and alkyl radicals to propagate the reaction. ${ }^{2}$ Substrates that add to give the corresponding Sn(Iv) compounds include alkyl iodides, bromides and chlorides with the rate decreasing in the order $\mathrm{I}>\mathrm{Br}>\mathrm{Cl}$, and for chloromethanes with $\mathrm{CCl}_{4}>\mathrm{HCCl}_{3}>\mathrm{H}_{2} \mathrm{CCl}_{2} .{ }^{7}$ Veith and co-workers observed oxidative addition of MeI and 1,2-dibromopentane to $\left[\mathrm{Sn}\left\{\mathrm{\kappa}^{2}-\mathrm{N}\left({ }^{t} \mathrm{Bu}\right) \mathrm{SiMe}_{2} \mathrm{~N}\left({ }^{t} \mathrm{Bu}\right)\right\}\right]$, whereas other 1,2-dihaloalkanes were dehalogenated to give the corresponding unsaturated hydrocarbons. ${ }^{8}$ A cyclic alkyl stannylene was also found to react with MeI, along with the non-chelated ditin species formed as a by-product in the synthesis of the cyclic stannylene. ${ }^{9}$ Reactions of a related cyclic alkyl stannylene with a combination of an aryliodide and an alkene demonstrated 
different reactivity as addition to the double bond and allylic $\mathrm{CH}$ bond activation were both observed with the ratio sensitive to the steric bulk on the aryliodide and alkene. ${ }^{10}$

Oxidation with elemental halogens has also been investigated. For example, $\mathrm{Br}_{2}$ undergoes oxidative addition with $\left[\mathrm{Sn}\left\{\mathrm{CH}\left(\mathrm{SiMe}_{3}\right)_{2}\right\}_{2}\right]$ to give the tin(Iv) dibromide species, ${ }^{11}$ whilst oxidation of four-coordinate salen and bis(dimethylaminonaphthyl) stabilised stannylenes has also been observed with $\mathrm{Br}_{2}$ and $\mathrm{I}_{2}$ forming the tin(Iv) dihalide species. ${ }^{12,13}$ Oxidation with elemental chalcogens allows the synthesis of tinchalcogenides which have been shown to have remarkably diverse bonding, ${ }^{14}$ including the stabilisation of $\mathrm{Sn}=\mathrm{E}(\mathrm{E}=$ chalcogen) multiple bonding (for example, $\mathrm{E}=\mathrm{S},{ }^{15} \mathrm{Se}^{16}$ and $\mathrm{Te}^{17}$ ) when the substituents on the tin atom are large enough ${ }^{18}$ or the tin centres are higher-coordinate, ${ }^{19-22}$ and tin-chalcogenides are also of current interest as they belong to the group 14-16 semiconductors which have a low band gap. ${ }^{19,23}$ Bridging Sn-E-Sn units are observed when the steric bulk of the aryl groups were reduced, ${ }^{24}$ and reactions of elemental chalcogens with the divalent $\mathrm{Sn}(\mathrm{II})$ amides $\left[\mathrm{Sn}\left\{\mathrm{N}\left(\mathrm{SiMe}_{3}\right)_{2}\right\}_{2}\right]$ and $\left[\mathrm{Sn}\left\{\kappa^{2}-\mathrm{N}\left({ }^{t} \mathrm{Bu}\right) \mathrm{SiMe}_{2} \mathrm{~N}\left({ }^{t} \mathrm{Bu}\right)\right\}\right]$ were shown to give $\mathrm{Sn}_{2} \mathrm{E}_{2}$ species containing four-membered rings. ${ }^{2,25-27}$

We have previously described the synthesis of saturated $\mathrm{N}$-heterocyclic stannylenes, ${ }^{28}$ and in collaboration with the group of Hahn, N-heterocyclic plumbylenes. ${ }^{29}$ Saturated $\mathrm{N}$-heterocyclic stannylenes were found to be much more thermally stable than the unsaturated $\mathrm{N}$-heterocyclic stannylenes reported by Gudat and co-workers, ${ }^{30,31}$ and this has allowed the coordination chemistry of these species to be revealed. ${ }^{32}$ In this publication we report on tin(Iv) chemistry of the same chelating diamide ligands formed by two routes; oxidation of the corresponding tin(II) species and synthesis directly from tin(IV) precursors generating new tin(Iv) alkyl, halide, chalcogenide and triflate complexes.

\section{Results and discussion}

\section{Dimethyldiamidotin compounds}

Three dimethyltindiamides containing bidentate diamido ligands were synthesised by reaction of the dilithiated diamines, generated from two equivalents of $\mathrm{Li}^{n} \mathrm{Bu}$ and the diamine as previously described, ${ }^{28}$ with $\mathrm{Me}_{2} \mathrm{SnCl}_{2}$ (Scheme 1). Reactions were performed in toluene for the more soluble lithium salts $\left(\mathrm{Li}_{2} \mathrm{~L}_{1}\right.$ and $\left.\mathrm{Li}_{2} \mathrm{~L}_{2}\right)$, whilst diethyl ether was used for $\mathrm{Li}_{2} \mathrm{~L}_{3}$. Crystallisation of the resulting tin(Iv) products gave poor yields (12-35\%) due to the very high solubility of all three compounds in hydrocarbon solvents despite the reactions proceeding with few by-products, but were enough for characterisation purposes. The diisopropylphenyl (Dipp) substituent in these ligands was a useful diagnostic tool in assessing the symmetry at the tin centre and potential rotation around the $\mathrm{N}$-aryl bond. For compounds 1 and 2, ${ }^{1} \mathrm{H}$ NMR spectroscopy revealed two sets of doublets for the isopropyl groups, along with a methine septet - an authentic septet for 2 due to equivalent ${ }^{3} J$ coupling to the inequivalent Me groups, but an apparent septet for 1 due to a $0.1 \mathrm{~Hz}$ difference in the analogous coupling - indicating that $\mathrm{N}$-aryl bond rotation is slower than the timescale of the experiment at room temperature. When heated to $70{ }^{\circ} \mathrm{C}$, compound 1 showed coalescence of the two doublets into a single doublet indicating onset of the high temperature regime averaging the two Me environments. ${ }^{1} \mathrm{H}$ NMR spectroscopy of compound 3, on the other hand, only showed one doublet for the Dipp methyl groups indicating averaging of the two environments at room temperature. The effect of constraining the tin atom in a 4-, 5-, or 6-membered ring was probed by ${ }^{119} \mathrm{Sn}$ NMR spectroscopy and showed a shift of the ${ }^{119} \mathrm{Sn}$ resonance to higher frequency with decreasing $\mathrm{N}-\mathrm{Sn}-\mathrm{N}$ angle, 2: -3 , 1: 33, 3: 98 ppm. X-ray crystallographic experiments were performed on single crystals of

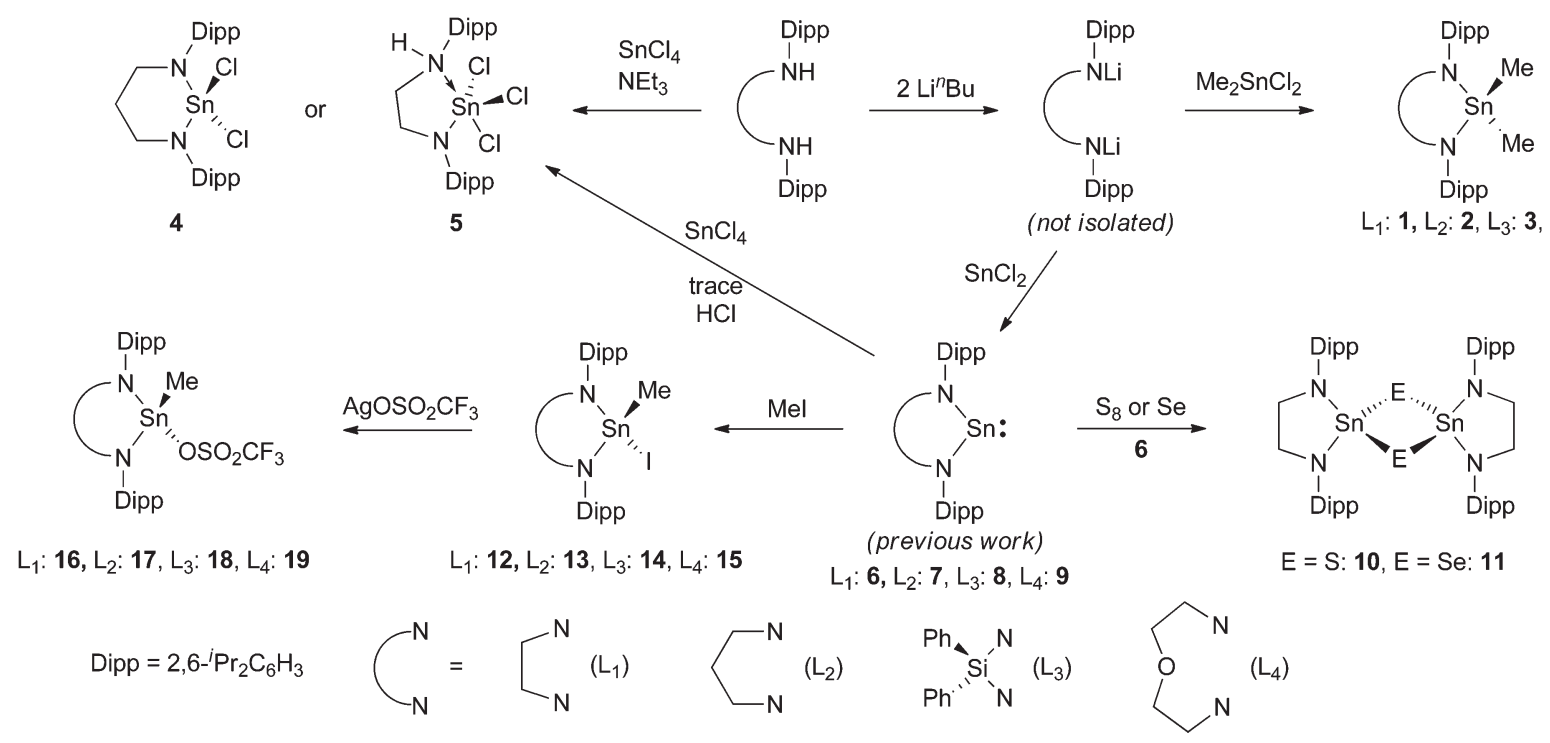

Scheme 1 Synthesis of tin compounds. 


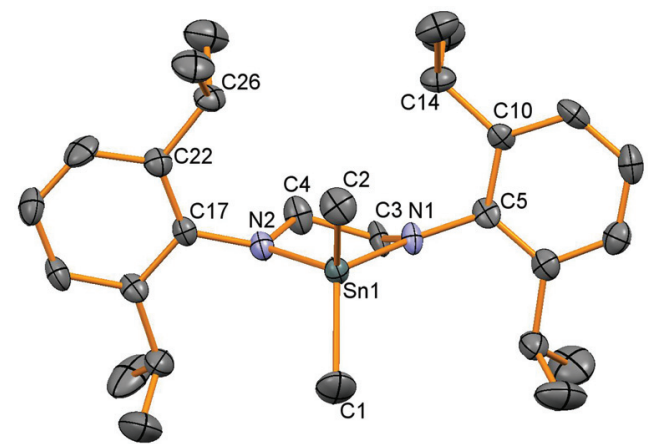

Fig. 1 Molecular structure of 1 . Hydrogen atoms have been removed for clarity and thermal ellipsoids are set at $50 \%$ probability.

Table 1 Selected bond distances $(\AA)$ and bond angles $\left({ }^{\circ}\right)$ for compounds 1-3

\begin{tabular}{llllr}
\hline 1 & $\mathrm{Sn}(1)-\mathrm{N}(1)$ & $2.000(4)$ & $\mathrm{N}(1)-\mathrm{Sn}(1)-\mathrm{N}(2)$ & $84.2(2)$ \\
& $\mathrm{Sn}(1)-\mathrm{N}(2)$ & $2.028(4)$ & $\mathrm{C}(1)-\mathrm{Sn}(1)-\mathrm{C}(2)$ & $114.3(2)$ \\
& $\mathrm{Sn}(1)-\mathrm{C}(1)$ & $2.127(6)$ & & \\
& $\mathrm{Sn}(1)-\mathrm{C}(2)$ & $2.107(5)$ & & \\
2 & $\mathrm{Sn}(1)-\mathrm{N}(1)$ & $2.033(3)$ & $\mathrm{N}(1)-\mathrm{Sn}(1)-\mathrm{N}(2)$ & $96.0(1)$ \\
& $\mathrm{Sn}(1)-\mathrm{N}(2)$ & $2.023(3)$ & $\mathrm{C}(28)-\mathrm{Sn}(1)-\mathrm{C}(29)$ & $114.7(2)$ \\
& $\mathrm{Sn}(1)-\mathrm{C}(28)$ & $2.139(4)$ & & \\
& $\mathrm{Sn}(1)-\mathrm{C}(29)$ & $2.120(5)$ & & $74.9(1)$ \\
& $\mathrm{Sn}(1)-\mathrm{N}(1)$ & $2.056(3)$ & $\mathrm{N}(1)-\mathrm{Sn}(1)-\mathrm{N}(2)$ & \\
& $\mathrm{Sn}(1)-\mathrm{N}(2)$ & $2.061(3)$ & $\mathrm{C}(37)-\mathrm{Sn}(1)-\mathrm{C}(38)$ & $112.5(2)$ \\
& $\mathrm{Sn}(1)-\mathrm{C}(37)$ & $2.122(4)$ & &
\end{tabular}

these three compounds, and a representative molecular structure is shown in Fig. 1 with selected data in Table 1 (see ESI $\dagger$ for figures of 2 and 3 ).

All three structures show tetrahedral tin centres bound to two methyl groups and two nitrogen atoms from the diamide ligand. The Dipp groups are situated perpendicular to the $\mathrm{N}-\mathrm{Sn}-\mathrm{N}$ plane in order to minimise steric clashes and show the anticipated four methyl groups pointing towards the tin substituents and four towards the ligand backbone. The Sn-C bond lengths are all similar and unremarkable. The nitrogen atoms are all planar, and the $\mathrm{Sn}-\mathrm{N}$ bond lengths are very similar to those observed in the corresponding Sn(II) compounds 6, 7 and $8^{28}$ possibly reflecting a balance of decreasing bond lengths anticipated for $\mathrm{Sn}$ (Iv) versus $\mathrm{Sn}$ (II) on covalent radii grounds, and the increase in bond length associated with higher coordination numbers. As anticipated, the largest effect was seen in the $\mathrm{N}-\mathrm{Sn}-\mathrm{N}$ angle which decreases with ring size; $96.0(1)^{\circ}$ for $2,84.2(2)^{\circ}$ for $\mathbf{1}$ and $74.9(1)^{\circ}$ for 3 , a pattern which is almost identical to those seen in the corresponding tin(II) compounds. $^{28}$

\section{Synthesis and characterisation of amidotin(Iv) chlorides}

Synthetically, chloride substituents are very useful for salt metathesis reactions so access to these species was targeted via two methods; oxidation of a Sn(II) compound and reactions from Sn(Iv) chloride. Following a literature precedent to generate amidotin chlorides, ${ }^{3} \mathrm{SnCl}_{4}$ was reacted with diamine $\left(\mathrm{L}_{2}\right) \mathrm{H}_{2}$ but a stoichiometric ratio of 4 equivalents of $\mathrm{NEt}_{3}$ and 2.6 equivalents of $\mathrm{SnCl}_{4}$ were required to drive the reaction towards completion (as shown by ${ }^{1} \mathrm{H}$ NMR spectroscopy). The product diamidotin dichloride $\mathbf{4}$ was obtained after recrystallization from $n$-hexane in $28 \%$ yield which was necessary to remove traces of unreacted diamine. ${ }^{1} \mathrm{H}$ NMR spectroscopy showed the same pattern of two doublets and a methine septet as anticipated from slow rotation of the $\mathrm{N}$-aryl bond and this did not coalesce upon heating to $65{ }^{\circ} \mathrm{C}$. Using selective NOE experiments, the doublet at $1.30 \mathrm{ppm}$ was assigned as the Dipp Me groups pointing towards the $\mathrm{CH}_{2}$ groups in the ligand backbone and ${ }^{119} \mathrm{Sn}$ NMR spectroscopy showed a signal at lower frequency $(-179 \mathrm{ppm})$ than 2 . X-ray crystallographic experiments on a single crystal of $\mathbf{4}$ revealed a molecular structure in accordance with the solution NMR spectroscopic data with a tetrahedral tin centre bonded to two planar nitrogen atoms and two chloride substituents (Fig. 2). The Sn-N bond distances (Table 2) are slightly shorter than for the dimethyl analogue 2 and the two $\mathrm{Sn}-\mathrm{Cl}$ bonds are of different length (Sn1-Cl1: 2.306 (1), Sn1-Cl2: 2.340(1) ̊).

Two reactions were attempted to generate the analogous diamidotin dichloride using the $\mathrm{L}_{1}$ ligand backbone, but yielded instead $\mathbf{5}$ with three chloride substituents and the ligand functioning as a mixed amide/amine donor. Thus stannylene 6 reacted with $\mathrm{SnCl}_{4}$ (and presumably trace $\mathrm{HCl}$ in this

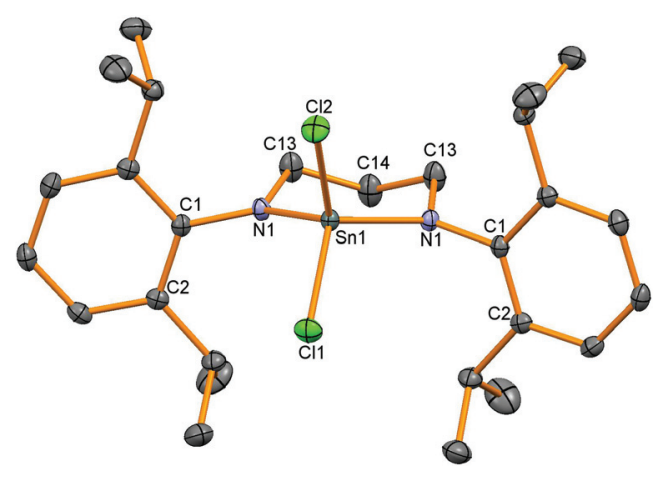

Fig. 2 Molecular structure of 4 . Hydrogen atoms have been removed for clarity and thermal ellipsoids are set at $50 \%$ probability.

Table 2 Selected bond distances ( $(\AA)$ and bond angles $\left({ }^{\circ}\right)$ for compounds 4 and 5 monoclinic

\begin{tabular}{llllr}
\hline 4 & $\mathrm{Sn}(1)-\mathrm{N}(1)$ & $1.981(1)$ & $\mathrm{N}(1)-\mathrm{Sn}(1)-\mathrm{N}(1 \mathrm{~A})$ & $100.0(1)$ \\
& $\mathrm{Sn}(1)-\mathrm{N}(1 \mathrm{~A})$ & $1.981(1)$ & $\mathrm{Cl}(1)-\mathrm{Sn}(1)-\mathrm{Cl}(2)$ & $100.6(1)$ \\
& $\mathrm{Sn}(1)-\mathrm{Cl}(1)$ & $2.306(1)$ & & \\
& $\mathrm{Sn}(1)-\mathrm{Cl}(2)$ & $2.340(1)$ & & \\
$\mathbf{5}$ & $\mathrm{Sn}(1)-\mathrm{N}(1)$ & $2.013(2)$ & $\mathrm{N}(1)-\mathrm{Sn}(1)-\mathrm{N}(2)$ & $78.2(1)$ \\
& $\mathrm{Sn}(1)-\mathrm{N}(2)$ & $2.340(3)$ & $\mathrm{N}$ (angles at N2) & 347.1 \\
& $\mathrm{Sn}(1)-\mathrm{Cl}(1)$ & $2.3665(9)$ & & \\
& $\mathrm{Sn}(1)-\mathrm{Cl}(2)$ & $2.3529(9)$ & & \\
& $\mathrm{Sn}(1)-\mathrm{Cl}(3)$ & $2.3206(10)$ & &
\end{tabular}




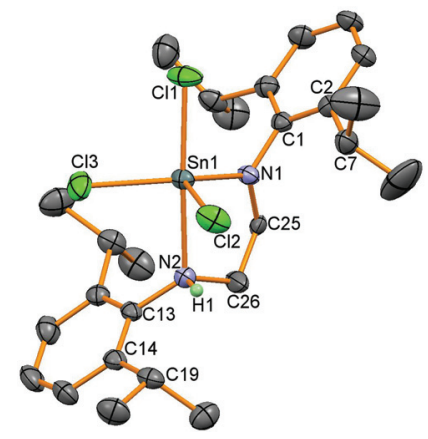

Fig. 3 Molecular structure of 5 . All hydrogen atoms except the $\mathrm{N}-\mathrm{H}$ have been removed for clarity and thermal ellipsoids are set at $50 \%$ probability.

reagent) to afford 5 in $25 \%$ yield; compound 5 was also synthesised from the reaction of $\left(\mathrm{L}_{1}\right) \mathrm{H}_{2}, \mathrm{SnCl}_{4}$ and $\mathrm{NEt}_{3}$ in $60 \%$ yield. In the stannylene oxidation reaction, one amido bond has been protonated whereas in the $\left(\mathrm{L}_{1}\right) \mathrm{H}_{2}$ reaction the second equivalent of $\mathrm{HCl}$ has not been removed by the $\mathrm{NEt}_{3}$ base. Asymmetry in the ligand was apparent from ${ }^{1} \mathrm{H}$ NMR spectroscopy which revealed two different $\mathrm{CH}_{2}$ environments for the ligand backbone, a set of two doublets with a corresponding apparent septet for one Dipp group and a broad signal for the methyl groups on the other Dipp substituent. An $\mathrm{N}-\mathrm{H}$ resonance is apparent at $5.46 \mathrm{ppm}$ which integrates as one proton and couples to a $\mathrm{CH}_{2}$ group. ${ }^{119} \mathrm{Sn}$ NMR spectroscopy showed a resonance at low frequency $(-303 \mathrm{ppm})$ indicative of a higher coordination number at tin compared to 4. Single crystals of the product were grown from both reactions and crystallisation from different solvents showed the same molecular structure (Fig. 3) but in different polymorphs; triclinic from toluene and monoclinc from $n$-hexane. Data for the monoclinic polymorph are discussed and given in Table 2, data for both polymorphs are in the ESI. $\dagger$

The molecular structures of 5 all showed 5-coordinate tin centres in trigonal-bipyramidal geometries with the amido group situated in the equatorial plane and the amine substituent axial as identified by the longer tin-amine bond lengths (2.340(3) $\AA$ ) and also by location by X-ray crystallography of the $\mathrm{H}$ atom attached to the nitrogen. The bond to the axial chloride substituent $(2.3665(9) \AA)$ is longer than the other two (2.3529(9) and 2.3206(10) $\AA$ ) as observed in the other polymorph. These observations indicate that the difference in the length of the carbon backbone in $\mathrm{L}_{1}$ and $\mathrm{L}_{2}$ has led to different reactivity with the abstraction of the final equivalent of $\mathrm{HCl}$ by $\mathrm{NEt}_{3}$ hindered when $\mathrm{L}_{1}$ is used.

\section{Stannylene oxidation with elemental chalcogens}

Oxidation of stannylene 6 with elemental sulfur or selenium was successfully carried out in thf solution, although oxidation using tellurium with or without additional $\mathrm{PPh}_{3}$ to form a more soluble tellurium transfer reagent was not successful. Good conversion to the chalcogenide products was achieved

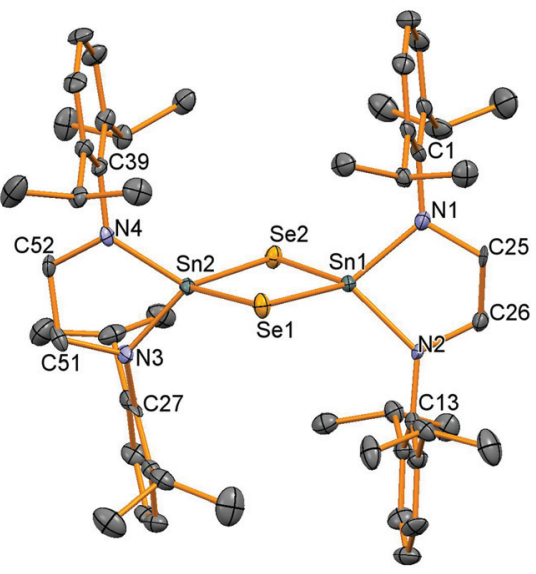

Fig. 4 Molecular structure of 11. All hydrogen atoms have been removed for clarity and thermal ellipsoids are set at $50 \%$ probability.

Table 3 Averaged bond distances $(\AA)$ and bond angles $\left({ }^{\circ}\right)$ for compounds 10 and 11 (two independent molecules in the unit cell)

\begin{tabular}{lllll}
\hline 10 & & & & \\
& & & & \\
& & & & \\
& Sn-S & 2.003 & Sn-N & 85.8 \\
& Sn-N & 2.407 & Sn-S & 95.3 \\
& Sn-Se & 2.002 & N-Sn-N & 85.4 \\
& 2.528 & Se-Sn-Se & 97.5
\end{tabular}

but traces of moisture also produced the diamine pro-ligand and upon recrystallisation to produce pure product yields of $20 \%$ were achieved for compounds 10 and 11, another indication of the high residual solubility of these compounds in hydrocarbon solvents even at low temperatures. ${ }^{1} \mathrm{H}$ NMR spectroscopy showed very similar resonances for both compounds, but ${ }^{119} \mathrm{Sn}$ NMR spectroscopy differentiated the two compounds with resonances at $-78 \mathrm{ppm}$ for $10\left({ }^{2} J_{(119) \mathrm{Sn}-(117) \mathrm{Sn}}=696 \mathrm{~Hz}\right)$ and $-320 \mathrm{ppm}$ for $\mathbf{1 1}$ with ${ }^{77}$ Se satellites (7.6\% abundant, $I=$ $1 / 2),{ }^{1} J_{\mathrm{Sn}-\mathrm{Se}}=1229 \mathrm{~Hz}$, similar to that seen for $(\mu-\mathrm{Se})_{2}[\mathrm{Sn}-$ $\left.\left\{\mathrm{N}\left(\mathrm{SiMe}_{3}\right)_{2}\right\}_{2}\right]_{2}(-383 \mathrm{ppm}, 1129 \mathrm{~Hz}){ }^{25}$

Single crystal X-ray diffraction experiments verified the bridged structure anticipated when the supporting ligand framework is not sterically encumbered enough to stabilise a $\mathrm{Sn}=\mathrm{E}$ double bond. Both compounds are isostructural with a $\mathrm{Sn}_{2} \mathrm{E}_{2}$ diamond joining the two tetrahedral tin centres (Fig. 4, Table 3). The only major difference between the structures is the longer Sn-Se bond lengths (av. 2.528 $\AA$ in 11) compared to Sn-S (av. 2.407 $\AA$ in 10). The Sn-N, Sn-S and Sn-Se bonds are very similar to those seen before in the bridging species $\left[(\mu-\mathrm{E}) \mathrm{Sn}\left\{\mathrm{N}\left(\mathrm{SiMe}_{3}\right)_{2}\right\}_{2}\right]_{2}(\mathrm{E}=\mathrm{S}: \mathrm{Sn}-\mathrm{N} 2.06 \AA$ A , Sn-S $2.416 \AA$; E = Se: Sn-N 2.049 A, Sn-Se 2.541 $\AA$, all averages $)^{25}$ and $[(\mu-S e) S n-$ $\left.\left(\mathrm{N}^{t} \mathrm{Bu}\right)_{2} \mathrm{SiMe}_{2}\right]_{2}(\mathrm{Sn}-\mathrm{N} 2.023(8) \AA$ A, Sn-Se 2.536(1) $\mathrm{\AA}) .{ }^{27}$

\section{Oxidation of N-heterocyclic stannylenes with MeI}

Oxidation of stannylenes with excess $\mathrm{MeI}$ in $\mathrm{Et}_{2} \mathrm{O}$ proceeded from isolated or in situ synthesised starting materials in a 
one pot reaction in reasonable yields of around $60 \%$ except for product $14(37 \%)$. A satisfactory combustion analysis could not be obtained for $\mathbf{1 3}$ despite repeated attempts, and this was also the case for $\mathbf{1 0}$ and 16. This variable success could be due to the high moisture sensitivity of the tinamide bond present in all the compounds leading to poor analyses. Oxidation of the $\mathrm{Sn}$ (II) compounds led to colourless or very-pale yellow tin(Iv) compounds and ${ }^{119} \mathrm{Sn}$ NMR spectroscopy showed a shift to lower frequency for resonances for all the compounds compared to the stannylenes (given in brackets, ppm): 12: -151 (6: 366), 13: -185 (7: 291), 14: -17 (8: 499), 15: -220 (9: 172). For compounds 12, 13 and 15, ${ }^{1} \mathrm{H}$ NMR spectroscopy revealed four doublet and two septet resonances for the isopropyl groups indicative of reduced symmetry compared to the starting materials. For compound 14, only two doublet and one septet resonances were observed as fast N-Ar bond rotation on the NMR timescale (as seen in the dimethyl analogue 3) averages the inequivalent ${ }^{\mathrm{i}} \mathrm{Pr}$ groups (leading to one methine resonance), but with two different tin substituents, this process no longer averages the inequivalent Me positions. Single crystal X-ray diffraction experiments were performed for all of these compounds and revealed four coordinate tetrahedral centres for 12-14 (Fig. 5 shows 14 as a representative example), whereas 15, with the additional donor atom in the ligand backbone, is five coordinate with an additional contact from the oxygen in the ligand backbone (Fig. ESI 15 $\dagger$ ). The data for 14 were of poorer quality than the other structures due to difficulties in achieving good diffraction from the thin needle-like crystals.

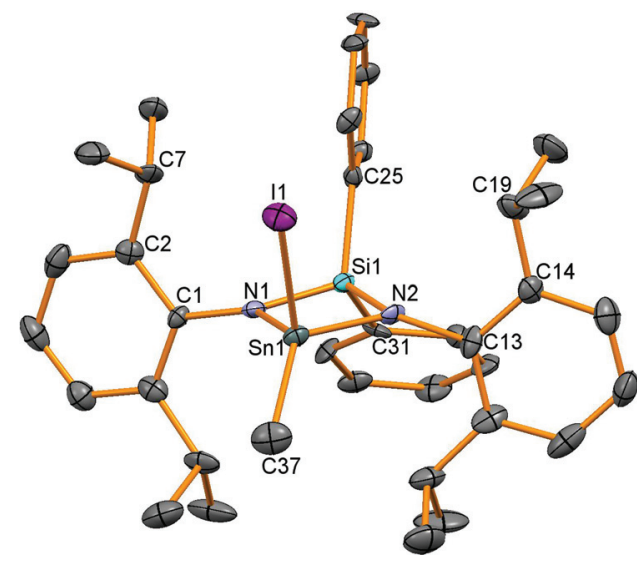

Fig. 5 Molecular structure of 14. All hydrogen atoms have been removed for clarity and thermal ellipsoids are set at $50 \%$ probability.

Bond lengths in these compounds are unremarkable (Table 4) and the $\mathrm{N}-\mathrm{Sn}-\mathrm{N}$ bond angles decrease from the wide bite-angle ligand $\mathrm{L}_{4}\left(\mathbf{1 5}\right.$ : $\left.125.17(17)^{\circ}\right)$ and then with decreasing chelate ring size; 13: 98.1, 12: 84.89(8), 14: 76.3(3) .

\section{Formation of tin triflates}

We were interested in using these tin iodides as precursors for generating cationic compounds with more weakly coordinating anions. Silicon compounds with the triflate anion (trifluoromethanesulfonate, OTf, $\left[\mathrm{OSO}_{2} \mathrm{CF}_{3}\right]^{-}$) are potent Lewis acids and have gained widespread use in many organic transformations. ${ }^{33}$ Tin triflates ${ }^{34}$ are much less studied than silicon tri-

Table 4 Selected bond distances $(\AA)$ and bond angles $\left(^{\circ}\right)$ for compounds 12-19

\begin{tabular}{|c|c|c|c|c|}
\hline & $\mathrm{Sn}-\mathrm{C}$ & $2.134(2)$ & $\mathrm{C}-\mathrm{Sn}-\mathrm{I}$ & $106.02(8)$ \\
\hline & Sn-I & $2.7184(2)$ & $\sum$ (angles at $\mathrm{Sn}$, not I) & 330.8 \\
\hline \multirow[t]{2}{*}{16} & $\mathrm{Sn}-\mathrm{N}$ & 1.991(3), 1.973(3) & $\overline{\mathrm{N}}-\mathrm{Sn}-\mathrm{N}$ & $87.20(11)$ \\
\hline & $\mathrm{Sn}-\mathrm{O}$ & $2.133(2)$ & $\sum$ (angles at Sn, not OTf) & 347.4 \\
\hline \multirow[t]{2}{*}{$13^{a}$} & $\mathrm{Sn}-\mathrm{N}$ & 2.003 & $\mathrm{~N}-\mathrm{Sn}-\mathrm{N}$ & 98.1 \\
\hline & $\mathrm{Sn}-\mathrm{C}$ & 2.110 & C-Sn-I & 107.1 \\
\hline & $\mathrm{Sn}-\mathrm{O}$ & 2.128 & $\sum$ (angles at Sn, not OTf) & 348.4 \\
\hline \multirow[t]{3}{*}{14} & $\mathrm{Sn}-\mathrm{N}$ & $2.031(8), 2.032(9)$ & $\mathrm{N}-\mathrm{Sn}-\mathrm{N}$ & $76.3(3)$ \\
\hline & $\mathrm{Sn}-\mathrm{C}$ & $2.151(12)$ & C-Sn-I & $105.2(3)$ \\
\hline & Sn-I & $2.7056(11)$ & $\sum$ (angles at $\mathrm{Sn}$, not I) & 329.9 \\
\hline \multirow[t]{2}{*}{18} & $\mathrm{Sn}-\mathrm{N}$ & $2.018(2), 2.011(2)$ & $\mathrm{N}-\mathrm{Sn}-\mathrm{N}$ & $77.56(8)$ \\
\hline & $\mathrm{Sn}-\mathrm{C}$ & $2.099(3)$ & $\mathrm{C}-\mathrm{Sn}-\mathrm{O}$ & $101.33(10)$ \\
\hline \multirow[t]{4}{*}{19} & $\mathrm{Sn}-\mathrm{N}$ & $2.012(2), 2.025(2)$ & $\mathrm{N}-\mathrm{Sn}-\mathrm{N}$ & 114.9(1) \\
\hline & $\mathrm{Sn}-\mathrm{O}$ & $2.325(2)$ & C-Sn-OTf & $100.20(11)$ \\
\hline & $\mathrm{Sn}-\mathrm{C}$ & $2.113(3)$ & & \\
\hline & Sn-OTf & $2.148(2)$ & & \\
\hline
\end{tabular}

${ }^{a}$ Average of two independent molecules. ${ }^{b}$ Disordered Me and I groups ( $\left.0.85: 0.15\right)$. Only data for major component is given. 
flates but have been used as Lewis-acid catalysts in a handful of organic transformations. ${ }^{35}$ There are a number of structurally characterised tin triflates, ${ }^{12,36-43}$ and examples of fourcoordinate tin triflates include $\left[\mathrm{Sn}\left\{\mathrm{CH}\left(\mathrm{SiMe}_{3}\right)_{2}\right\}_{3} \mathrm{OTf}\right]$ synthesised by protonation of the corresponding tin hydride using HOTf ${ }^{44}$ and another from protonation of a strained [2]ferrocenophane with a $\mathrm{CH}_{2} \mathrm{Sn}\left({ }^{t} \mathrm{Bu}\right)_{2}$ bridge forming a fourcoordinate tin triflate. ${ }^{45}$ Reactions of AgOTf with 12-15 were carried out generating the corresponding tin triflates 16, 17 and 19 but ${ }^{1} \mathrm{H}$ NMR spectroscopy revealed that reactions to generate 18 also generated other unidentified by-products which could not be separated. Problems in generating tin triflates containing $\mathrm{Si}$ substituents have been noted before. ${ }^{46}$ ${ }^{119}$ Sn NMR spectroscopy showed resonances at -155 for 16 , -95 for 17 and -152 ppm for 19 and ${ }^{19} \mathrm{~F}$ NMR spectroscopy showed very similar resonances for the triflate anion (16: -78 , 17: $-77,19:-77 \mathrm{ppm})$. Single crystals were grown for all the products and selected data are given in Table 4 . The tin-triflate bond lengths are similar for all the compounds (2.125(2)2.148(2) $\AA$ ) and shorter than in the related compound [ $\mathrm{Sn}(\mathrm{Me})$ $\left.\operatorname{OTf}\left\{\kappa^{2}-\mathrm{N}\left({ }^{t} \mathrm{Bu}\right) \mathrm{SiMe}_{2} \mathrm{~N}\left({ }^{t} \mathrm{Bu}\right)\right\}_{2}\right]_{n}$ (2.327 and $\left.2.412 \AA\right)$ which was found to be five-coordinate with bridging triflate anions. ${ }^{41}$ There are only very marginal differences in the Sn-N and Sn-C bond lengths compared to the methyliodide compounds for 16-18, however, compound 19 shows a much shorter oxygen contact with the backbone of ligand (19: Sn1-O1 2.325(2) A, 15: Sn1-O1 2.518(4) A). The geometry around the 4-coordinate tin atoms had shown the greatest change between the starting material and the product as the sum of the angles around the tin centre, excluding the iodide or triflate group, had increased from the iodide compounds ( $\mathrm{ca} .330^{\circ}$ as expected for tetrahedral coordination) to $c a$. $347^{\circ}$ indicative of a geometry intermediate between tetrahedral and trigonal planar with an apical OTf group ( $360^{\circ}$ for trigonal planar atoms). The tin centre in 19 is five-coordinate (Fig. 6) and has a $\tau$ value $^{47}$ of 0.64 ( $c f .0 .65$ in 15).

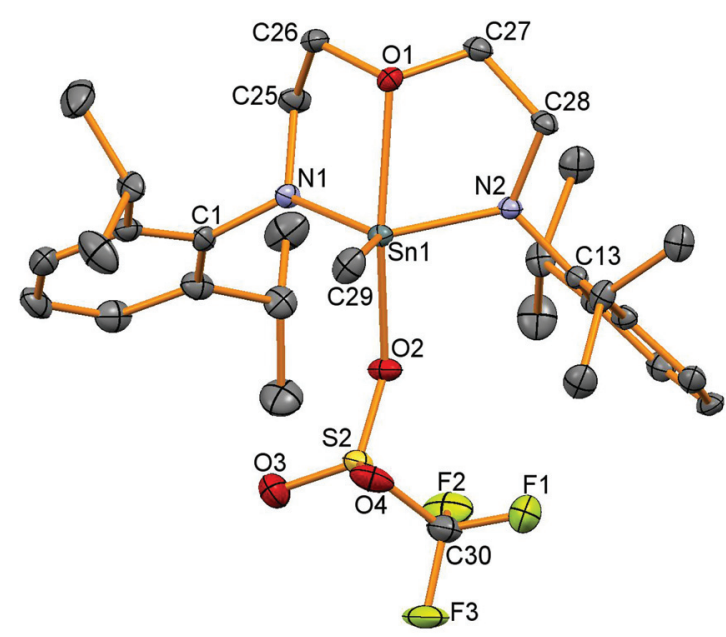

Fig. 6 Molecular structure of 19. All hydrogen atoms have been removed for clarity and thermal ellipsoids are set at $50 \%$ probability.

\section{Experimental}

\section{General synthetic details}

All air- and moisture-sensitive materials were weighed out, isolated, and stored in an argon-filled Saffron Beta glove box. Standard Schlenk-line techniques were used with filtrations carried out using Celite and a porosity 3 sinter. The solvents used were distilled HPLC grade and further dried and degassed using a commercially available solvent purification system (Anhydrous Engineering). Deuterated benzene was dried over potassium then vacuum transferred and kept over molecular sieves in the glove box. Elemental compositions (C, $\mathrm{H}$ and $\mathrm{N}$ ) were determined by sealing samples in air-tight aluminium boats in a glove-box and were recorded on a Carlo Erba EA1108 CHN elemental analyser or by Mr Stephen Boyer (London Metropolitan University). Despite several attempts, satisfactory analyses could not be obtained for 3 out of the 14 compounds. This is most likely due to the high sensitivity of the tin-amide bond to trace water. Solution NMR spectroscopy samples were prepared using dry and degassed deuterated solvent in air-tight NMR tubes sealed with a Youngs tap. ${ }^{119} \mathrm{Sn}$ and ${ }^{29} \mathrm{Si} \mathrm{NMR}$ spectra were run on Jeol Eclipse and Lambda $300 \mathrm{MHz}$ spectrometers and referenced to external samples of $\mathrm{SnMe}_{4}$ and $\mathrm{SiMe}_{4}$ respectively. ${ }^{1} \mathrm{H}$ and ${ }^{13} \mathrm{C}$ NMR spectra were run on Jeol Eclipse 300, Lambda 300 and Delta $270 \mathrm{MHz}$ spectrometers and were referenced to the internal solvent peaks. Septet is abbreviated sep. Mass spectrometry samples were run on a VG Autospec spectrometer. The N-heterocyclic stannylenes and diamines were synthesised as reported previously. ${ }^{28}$

\section{General method for the synthesis of dimethyl tin compounds}

The appropriate diamine $(1.08 \mathrm{mmol})$ was dissolved in toluene $\left(20 \mathrm{~cm}^{3}\right)$, cooled to $-78{ }^{\circ} \mathrm{C}$ and ${ }^{n} \mathrm{BuLi}$ (1.6 $\mathrm{M}$ in $n$-hexane, $1.4 \mathrm{~cm}^{3}, 2.15 \mathrm{mmol}$ ) was added dropwise. The yellow solution was allowed to warm to room temperature and then left to stir overnight. $\mathrm{Me}_{2} \mathrm{SnCl}_{2}(0.237 \mathrm{~g}, 1.08 \mathrm{mmol})$ was added under positive pressure of nitrogen at $0{ }^{\circ} \mathrm{C}$ and the reaction was stirred overnight at room temperature, filtered and then recrystallised directly from a minimum amount of toluene.

Analytical data for $\left[\operatorname{SnMe}_{2}\left(\mathrm{~L}_{1}\right)\right]$ (1). Using diamine $\left(\mathrm{L}_{1}\right) \mathrm{H}_{2}$, crystallised from toluene at $-25{ }^{\circ} \mathrm{C}$, yield: $67 \mathrm{mg}, 0.13 \mathrm{mmol}$, $12 \% .{ }^{1} \mathrm{H}$ NMR $\left(300 \mathrm{MHz}, 25{ }^{\circ} \mathrm{C}, \mathrm{C}_{6} \mathrm{D}_{6}\right): \delta(\mathrm{ppm}) 7.10(\mathrm{~m}, 6 \mathrm{H}$, Ar- $H$ ), 3.81 (app. sep, ${ }^{3} J_{\mathrm{HH}}=6.8$ and $6.9 \mathrm{~Hz}, 4 \mathrm{H}$, Dipp-CH), 3.41 (s with unresolved ${ }^{119} \mathrm{Sn}$ and ${ }^{117} \mathrm{Sn}$ satellites ${ }^{3} J_{\mathrm{HSn}} \approx 29 \mathrm{~Hz}$, $\mathrm{CH}_{2} \mathrm{NSn}$ ), 1.27 (d, ${ }^{3} J_{\mathrm{HH}}=6.8 \mathrm{~Hz}, 12 \mathrm{H}$, Dipp-CH $\left.\mathrm{CH}_{3}\right), 1.21$ $\left(\mathrm{d},{ }^{3} J_{\mathrm{HH}}=6.9 \mathrm{~Hz}, 12 \mathrm{H}\right.$, Dipp-CH3 $), 0.19$ (s with ${ }^{119} \mathrm{Sn}$ and ${ }^{117} \mathrm{Sn}$ satellites, ${ }^{2} J_{\mathrm{H}(119) \mathrm{Sn}}=62.0 \mathrm{~Hz}{ }^{2} J_{\mathrm{H}(117) \mathrm{Sn}}=59.0 \mathrm{~Hz}$, $\left.\mathrm{Sn}-\mathrm{CH}_{3}\right) .{ }^{13} \mathrm{C}$ NMR (75.4 MHz, $\left.25{ }^{\circ} \mathrm{C}, \mathrm{C}_{6} \mathrm{D}_{6}\right): \delta$ (ppm) 148.6 (Ar- $C_{i p s o}$ ), 146.8 (Ar- $\left.C_{\text {ortho }}\right), 125.1$ (Ar- $\left.C_{\text {para }}\right), 123.7$ (Ar- $\left.C_{\text {meta }}\right)$, $57.2\left(\mathrm{CH}_{2} \mathrm{~N}\right), 27.9$ (Dipp-CH), 25.7 (Dipp- $\left.\mathrm{CH}_{3}\right), 24.5$ (Dipp$\left.\mathrm{CH}_{3}\right),-2.7\left(\mathrm{Sn}-\mathrm{CH}_{3}\right) .{ }^{119} \mathrm{Sn} \mathrm{NMR}\left(111.9 \mathrm{MHz}, 25{ }^{\circ} \mathrm{C}, \mathrm{C}_{6} \mathrm{D}_{6}\right)$ : $\delta(\mathrm{ppm})$ 33. Elemental analysis calculated for $\mathrm{C}_{28} \mathrm{H}_{44} \mathrm{~N}_{2} \mathrm{Sn}(\%)$ : C 63.77, H 8.41 N 5.31. Found (\%): C 64.35, H 8.56 N 5.25.

Analytical data for $\left[\operatorname{SnMe}_{2}\left(\mathbf{L}_{2}\right)\right](2)$. Using diamine $\left(\mathrm{L}_{2}\right) \mathrm{H}_{2}$, crystallised from toluene after storage at $-25{ }^{\circ} \mathrm{C}$, yield: $0.256 \mathrm{~g}$, $0.473 \mathrm{mmol}, 35 \%$. ${ }^{1} \mathrm{H}$ NMR (300 $\left.\mathrm{MHz}, \mathrm{C}_{6} \mathrm{D}_{6}\right): \delta$ (ppm) 
7.16-7.00 (m, 6H, Ar- $H$ ), $3.90\left(\mathrm{sep},{ }^{3} J_{\mathrm{HH}}=6.9 \mathrm{~Hz}, 4 \mathrm{H}\right.$, Dipp$\mathrm{CH}), 3.41-3.73\left(\mathrm{~m}, 4 \mathrm{H}, \mathrm{NCH}_{2}\right), 1.97\left(\mathrm{~m}, 2 \mathrm{H}, \mathrm{NCH}_{2} \mathrm{CH}_{2} \mathrm{CH}_{2} \mathrm{~N}\right)$, $1.37\left(\mathrm{~d},{ }^{3} J_{\mathrm{HH}}=6.9 \mathrm{~Hz}, 12 \mathrm{H}\right.$, Dipp-CH $\left.H_{3}\right), 1.29\left(\mathrm{~d},{ }^{3} J_{\mathrm{HH}}=6.9 \mathrm{~Hz}\right.$, $12 \mathrm{H}$, Dipp- $\mathrm{CH}_{3}$ ), 0.16 (s with ${ }^{119} \mathrm{Sn}$ and ${ }^{117} \mathrm{Sn}$ satellites, $\left.{ }^{2} J_{\mathrm{H}(119) \mathrm{Sn}}=61.4 \mathrm{~Hz}{ }^{2} J_{\mathrm{H}(117) \mathrm{Sn}}=58.8 \mathrm{~Hz}, 6 \mathrm{H}, \mathrm{Sn}-\mathrm{CH}_{3}\right) \cdot{ }^{13} \mathrm{C} \mathrm{NMR}$ $\left(75.4 \mathrm{MHz}, 25{ }^{\circ} \mathrm{C}, \mathrm{C}_{6} \mathrm{D}_{6}\right): \delta(\mathrm{ppm}) 148.9$ (Ar- $\left.C_{\text {ipso }}\right), 147.0$ (Ar- $\left.C_{\text {ortho }}\right), 125.5$ (Ar- $\left.C_{\text {para }}\right), 123.8\left(\right.$ Ar- $\left.C_{\text {meta }}\right), 56.7\left(\mathrm{CH}_{2} \mathrm{~N}\right), 33.8$ $\left(\mathrm{NCH}_{2} \mathrm{CH}_{2} \mathrm{CH}_{2} \mathrm{~N}\right.$ ), 27.7 (Dipp-CH), 26.1 (Dipp- $\mathrm{CH}_{3}$ ), 24.7 (Dipp$\left.\mathrm{CH}_{3}\right),-2.5\left(\mathrm{Sn}-\mathrm{CH}_{3}\right) .{ }^{119} \mathrm{Sn}$ NMR $\left(111.9 \mathrm{MHz}, 25{ }^{\circ} \mathrm{C}, \mathrm{C}_{6} \mathrm{D}_{6}\right)$ : $\delta(\mathrm{ppm})-3$. Elemental analysis calculated for $\mathrm{C}_{29} \mathrm{H}_{46} \mathrm{~N}_{2} \mathrm{Sn}(\%)$ : C 64.34 H 8.56 N 5.17. Found (\%): C 64.08 H 7.88 N 4.97. Mass spectrometry (E.I.): $m / z 543\left(\mathbf{M}^{+}+\mathrm{H}\right), 527\left(\mathrm{M}^{+}-\mathrm{CH}_{3}\right.$ with correct isotopic distribution).

Analytical data for $\left[\operatorname{SnMe}_{2}\left(\mathrm{~L}_{3}\right)\right]$ (3). Using diamine $\left(\mathrm{L}_{3}\right) \mathrm{H}_{2}$ (1.195 $\mathrm{g}, 2.23 \mathrm{mmol}), \mathrm{Et}_{2} \mathrm{O}\left(40 \mathrm{~cm}^{3}\right)$ as the reaction solvent and $n$-hexane $\left(30 \mathrm{~cm}^{3}\right)$ as the extraction solvent gave a colourless solid $(0.926 \mathrm{~g}, 61 \%)$ which was recrystallised from $n$-hexane in $15 \%$ yield. ${ }^{1} \mathrm{H}$ NMR (300 MHz, $\left.25{ }^{\circ} \mathrm{C}, \mathrm{C}_{6} \mathrm{D}_{6}\right): \delta(\mathrm{ppm}) 7.46-7.43$ (m, 4H, Ar-H), 7.17 (m, 2H, Ar-H), 7.07-7.01 (m, 10H, Ar- $H$ ), $5.44\left(\mathrm{sep},{ }^{3} J_{\mathrm{HH}}=6.8 \mathrm{~Hz}, 4 \mathrm{H}, \mathrm{Dipp}-\mathrm{CH}\right), 1.06\left(\mathrm{~d},{ }^{3} J_{\mathrm{HH}}=6.8 \mathrm{~Hz}\right.$, $24 \mathrm{H}$, Dipp- $\mathrm{CH}_{3}$ ), 0.65 (s with ${ }^{119} \mathrm{Sn}$ and ${ }^{117} \mathrm{Sn}$ satellites ${ }^{2} J_{\mathrm{H}(119) \mathrm{Sn}}=58.9 \mathrm{~Hz}$ and $\left.{ }^{2} J_{\mathrm{H}(117) \mathrm{Sn}}=56.3 \mathrm{~Hz}, 6 \mathrm{H}, \mathrm{Sn}-\mathrm{CH}_{3}\right)$. ${ }^{13} \mathrm{C}$ NMR (75.4 MHz, $\left.25{ }^{\circ} \mathrm{C}, \mathrm{C}_{6} \mathrm{D}_{6}\right): \delta(\mathrm{ppm}) 147.2,142.4,139.8$, 135.5, 129.4, 127.4, 124.1, 124.0 (collection of $\mathrm{Ar}-C$ ), 28.3 (Dipp-CH), $25.2\left(\right.$ Dipp- $\left.\mathrm{CH}_{3}\right), 3.9\left(\mathrm{Sn}-\mathrm{CH}_{3}\right) .{ }^{29} \mathrm{Si} \mathrm{NMR}(59.6 \mathrm{MHz}$, $\left.25{ }^{\circ} \mathrm{C}, \mathrm{C}_{6} \mathrm{D}_{6}\right): \delta(\mathrm{ppm})-22 .{ }^{119} \mathrm{Sn} \mathrm{NMR}\left(111.9 \mathrm{MHz}, 25{ }^{\circ} \mathrm{C}\right.$, $\left.\mathrm{C}_{6} \mathrm{D}_{6}\right): \quad \delta(\mathrm{ppm})$ 98. Elemental analysis calculated for $\mathrm{C}_{38} \mathrm{H}_{50} \mathrm{~N}_{2} \mathrm{SiSn}$ (\%): C $66.96 \mathrm{H} 7.39 \mathrm{~N}$ 4.11. Found (\%): C 66.76 H 7.26 N 4.13 .

Analytical data for $\left[\operatorname{SnCl}_{2}\left(\mathbf{L}_{2}\right)\right]$ (4). To a $-78{ }^{\circ} \mathrm{C}$ solution of $\left(\mathrm{L}_{2}\right) \mathrm{H}_{2}(0.613 \mathrm{~g}, 1.55 \mathrm{mmol})$ and triethylamine $\left(0.86 \mathrm{~cm}^{3}\right.$, $6.2 \mathrm{mmol}, 4$ equiv. $)$ in toluene $\left(15 \mathrm{~cm}^{3}\right)$ was added $1 \mathrm{M} \mathrm{SnCl}_{4}$ in $n$-hexane $\left(4.0 \mathrm{~cm}^{3}, 4.0 \mathrm{mmol}, 2.6\right.$ equiv.) and the mixture was stirred for 3 days after which all of the volatiles were removed under vacuum. The residue was extracted into $n$-hexane $\left(30 \mathrm{~cm}^{3}\right)$ and filtered giving a clear, pale yellow solution which was concentrated under reduced pressure and pale yellow crystals formed after storage at $-25{ }^{\circ} \mathrm{C}(0.255 \mathrm{~g}$, $0.438 \mathrm{mmol}, 28 \%$ yield). ${ }^{1} \mathrm{H}$ NMR (300 MHz, $\left.25{ }^{\circ} \mathrm{C}, \mathrm{C}_{6} \mathrm{D}_{6}\right)$ : $\delta(\mathrm{ppm}) 7.20-7.12(\mathrm{~m}, 6 \mathrm{H}, \mathrm{Ar}-H), 3.87\left(\mathrm{sep},{ }^{3} J_{\mathrm{HH}}=7.0 \mathrm{~Hz}, 4 \mathrm{H}\right.$, Dipp-CH), $3.33\left(\mathrm{t},{ }^{3} J_{\mathrm{HH}}=5.1 \mathrm{~Hz}\right.$, unresolved ${ }^{119} \mathrm{Sn}$ and ${ }^{117} \mathrm{Sn}$ satellites ${ }^{3} J_{\mathrm{HSn}} \approx 35 \mathrm{~Hz} 4 \mathrm{H}, \mathrm{NCH}_{2}$ ), 1.87 (quintet, ${ }^{3} J_{\mathrm{HH}}=$ $\left.5.1 \mathrm{~Hz}, 2 \mathrm{H}, \mathrm{NCH}_{2} \mathrm{CH}_{2} \mathrm{CH}_{2} \mathrm{~N}\right), 1.43\left(\mathrm{~d},{ }^{3} J_{\mathrm{HH}}=7.0 \mathrm{~Hz}, 12 \mathrm{H}\right.$ Dipp$\left.\mathrm{CH}_{3}\right), 1.33\left(\mathrm{~d},{ }^{3} J_{\mathrm{HH}}=7.0 \mathrm{~Hz}, 12 \mathrm{H}\right.$, Dipp-CH$) .{ }^{13} \mathrm{C} \mathrm{NMR}$ (75.5 MHz, $\left.25{ }^{\circ} \mathrm{C}, \mathrm{C}_{6} \mathrm{D}_{6}\right): \delta(\mathrm{ppm}) 149.0$ (Ar- $\left.C_{\text {ortho }}\right), 143.2$ (Ar- $C_{\text {ipso }}$ ), 127.8 (Ar- $\left.C_{\text {para }}\right), 124.9$ (Ar- $\left.C_{\text {meta }}\right), 59.0\left(\mathrm{NCH}_{2}\right.$ with unresolved ${ }^{119} \mathrm{Sn}$ and ${ }^{117} \mathrm{Sn}$ satellites $\left.{ }^{3} J_{\mathrm{CSn}} \approx 12 \mathrm{~Hz}\right), 34.0$ $\left(\mathrm{NCH}_{2} \mathrm{CH}_{2} \mathrm{CH}_{2} \mathrm{~N}\right.$ ), 28.8 (Dipp- $\mathrm{CH}$ ), 26.4 (Dipp-CH $\mathrm{CH}_{3}$ ), 25.1 (Dipp$\left.\mathrm{CH}_{3}\right) .{ }^{119} \mathrm{Sn} \mathrm{NMR}\left(111.9 \mathrm{MHz}, 25{ }^{\circ} \mathrm{C}, \mathrm{C}_{6} \mathrm{D}_{6}\right): \delta(\mathrm{ppm})-179$. Elemental analysis calculated for $\mathrm{C}_{27} \mathrm{H}_{40} \mathrm{Cl}_{2} \mathrm{~N}_{2} \mathrm{Sn}$ (\%): C 55.70 H 6.92 N 4.81. Found (\%): C 56.07 H 7.06 N 4.76.

$\left[\operatorname{SnCl}_{3}\left\{\boldsymbol{\kappa}^{2}-\operatorname{DippN}(\mathbf{H}) \mathbf{C H}_{2} \mathbf{C H}_{2} \mathbf{N}(\operatorname{Dipp})\right\}\right]$ (5). Method A: To a $-78{ }^{\circ} \mathrm{C}$ solution of $\left\{\mathrm{CH}_{2} \mathrm{~N}(\mathrm{Dipp})\right\}_{2} \mathrm{Sn}(6)(0.390 \mathrm{~g}, 0.78 \mathrm{mmol})$ dissolved in $n$-hexane/toluene $\left(25 \mathrm{~cm}^{3} / 10 \mathrm{~cm}^{3}\right)$ was added a solution of $\mathrm{SnCl}_{4}$ in $n$-hexane $\left(1 \mathrm{M}, 0.78 \mathrm{~cm}^{3}, 0.78 \mathrm{~mol}, 1\right.$ equiv.). The solution immediately turned cloudy and after stirring overnight all of the volatiles were removed under reduced pressure. The product was redissolved in $n$-hexane $\left(30 \mathrm{~cm}^{3}\right)$, filtered and concentrated under reduced pressure yielding pale yellow crystals after storage at $5{ }^{\circ} \mathrm{C}$ overnight (0.119 g, $0.20 \mathrm{mmol}, 25 \%$ yield).

$\left[\mathrm{SnCl}_{3}\left\{\kappa^{2}-\operatorname{DippN}(\mathbf{H}) \mathrm{CH}_{2} \mathrm{CH}_{2} \mathbf{N}(\mathrm{Dipp})\right\}\right]$ (5). Method B: To a $-78{ }^{\circ} \mathrm{C}$ solution of $\left(\mathrm{L}_{1}\right) \mathrm{H}_{2}(1.01 \mathrm{~g}, 2.66 \mathrm{mmol})$ and triethylamine $(0.74 \mathrm{~mL}, 2$ equiv., $5.31 \mathrm{mmol})$ in toluene $\left(60 \mathrm{~cm}^{3}\right)$ was added $1 \mathrm{M} \mathrm{SnCl}_{4}$ in $n$-hexane $\left(5.4 \mathrm{~cm}^{3}, 5.4 \mathrm{mmol}, 2\right.$ equiv.) and the mixture was stirred at room temperature for 2 days. Filtration gave a clear yellow solution which was concentrated under reduced pressure and the product crystallised at $-25{ }^{\circ} \mathrm{C}$ (0.961 g, $1.59 \mathrm{mmol}, 60 \%)$.

Analytical data for $5 .{ }^{1} \mathrm{H}$ NMR (300 MHz, $\left.25{ }^{\circ} \mathrm{C}, \mathrm{C}_{6} \mathrm{D}_{6}\right)$ : $\delta(\mathrm{ppm})$ 7.27-7.16 (m, 3H, Ar-H), 7.06-6.99 (m, 3H, Ar- $H$ ), 5.46 $\left(\mathrm{t},{ }^{3} J_{\mathrm{HH}}=7.2 \mathrm{~Hz}, 1 \mathrm{H}, \mathrm{NH}\right.$ ), 3.66 (app. sep, ${ }^{3} J_{\mathrm{HH}}=6.8$ and 7.0 $\mathrm{Hz}, 2 \mathrm{H}$, Dipp-CH) 3.21-3.13 (m, 4H, Dipp-CH and $\mathrm{CH}_{2}$ ), 2.97-2.91 (m, 2H, $\left.\mathrm{CH}_{2}\right), 1.53\left(\mathrm{~d},{ }^{3} \mathrm{~J}_{\mathrm{HH}}=7.0 \mathrm{~Hz}, 6 \mathrm{H}, \mathrm{Dipp}-\mathrm{CH}_{3}\right)$, $1.35\left(\mathrm{~d},{ }^{3} J_{\mathrm{HH}}=6.8 \mathrm{~Hz}, 6 \mathrm{H}\right.$, Dipp-CH ), 1.26 (br. s, 12H, Dipp$\mathrm{CH}_{3}$ attached to protonated $\mathrm{N}$ atom). ${ }^{13} \mathrm{C} \mathrm{NMR}(75.5 \mathrm{MHz}$, $\left.25{ }^{\circ} \mathrm{C}, \mathrm{C}_{6} \mathrm{D}_{6}\right): \delta(\mathrm{ppm}) 148.7$ (Ar- $C$ ), 142.0 (Ar- $C$ ), $141.6(\mathrm{Ar}-C)$, 138.8 (Ar- $C$ ), 127.7 (Ar- $C H$ ), $127.5(\mathrm{Ar}-\mathrm{CH}), 125.3(\mathrm{Ar}-\mathrm{CH}), 124.4$ $(\mathrm{Ar}-\mathrm{CH}), 50.6\left(\mathrm{CH}_{2}\right), 49.6\left(\mathrm{CH}_{2}\right), 29.4\left({ }^{\mathrm{i}} \mathrm{Pr}-\mathrm{C}\right), 28.7\left({ }^{\mathrm{i}} \mathrm{Pr}-\mathrm{C}\right), 25.6$ $\left({ }^{\mathrm{i}} \mathrm{Pr}-C\right), 24.8\left({ }^{\mathrm{i}} \mathrm{Pr}-C\right), 24.5\left({ }^{\mathrm{i}} \mathrm{Pr}-C\right) .{ }^{119} \mathrm{Sn}$ NMR $\left(111.9 \mathrm{MHz}, 25{ }^{\circ} \mathrm{C}\right.$, $\left.\mathrm{C}_{6} \mathrm{D}_{6}\right): \delta(\mathrm{ppm})-303(\mathrm{~s})$. Elemental analysis calculated for $\mathrm{C}_{26} \mathrm{H}_{39} \mathrm{Cl}_{3} \mathrm{~N}_{2} \mathrm{Sn}(\%)$ : C $51.65 \mathrm{H} 6.50 \mathrm{~N}$ 4.63. Found (\%): C 51.73 H 6.59 N 4.79.

\section{General method for oxidation with $\mathrm{S}_{\mathbf{8}}$ and $\mathrm{Se}$}

Excess chalcogen $\left(\mathrm{S}_{8}: 0.985 \mathrm{~g}, 3.8 \mathrm{mmol}\right.$, Se: $238 \mathrm{mg}$, $3.0 \mathrm{mmol}$ ) was added to a $-78{ }^{\circ} \mathrm{C}$ solution of 6 (1.91 g, $3.8 \mathrm{mmol}$ and $238 \mathrm{mg}, 0.48 \mathrm{mmol}$ respectively) in thf and was then stirred at room temperature overnight. The solvent was removed under vacuum and the product was extracted into $n$-hexane $\left(30 \mathrm{~cm}^{3}\right)$ and filtered. The solution was concentrated under reduced pressure forming a crystalline solid after storage at $-20{ }^{\circ} \mathrm{C}$ overnight.

Analytical data for $\left[\left\{\operatorname{Sn}\left(\mathbf{L}_{\mathbf{1}}\right)(\boldsymbol{\mu}-\mathbf{S})\right\}_{2}\right]$ (10). Yield: $0.412 \mathrm{~g}$, $0.39 \mathrm{mmol}, 20 \% .{ }^{1} \mathrm{H}$ NMR $\left(300 \mathrm{MHz}, 25{ }^{\circ} \mathrm{C}, \mathrm{C}_{6} \mathrm{D}_{6}\right): \delta(\mathrm{ppm})$ 7.18-7.06 (m, 6H, Ar-H), 3.67 (sep, ${ }^{3} J_{\mathrm{HH}}=6.8 \mathrm{~Hz}, 4 \mathrm{H}$, Dipp$\mathrm{CH}$ ), 3.37 (s with unresolved ${ }^{119} \mathrm{Sn}$ and ${ }^{117} \mathrm{Sn}$ satellites ${ }^{3} \mathrm{~J}_{\mathrm{HSn}} \approx$ $57 \mathrm{~Hz}, 4 \mathrm{H}, \mathrm{CH}_{2}$ ), 1.24 (d, $\left.{ }^{3} J_{\mathrm{HH}}=6.8 \mathrm{~Hz}, 12 \mathrm{H}, \mathrm{Dipp}-\mathrm{CH}_{3}\right), 1.17$ $\left(\mathrm{d},{ }^{3} J_{\mathrm{HH}}=6.8 \mathrm{~Hz}, 12 \mathrm{H}\right.$, Dipp-CH$) .{ }^{13} \mathrm{C} \mathrm{NMR}(75.5 \mathrm{MHz}$, $\left.25{ }^{\circ} \mathrm{C}, \mathrm{C}_{6} \mathrm{D}_{6}\right): \delta(\mathrm{ppm}) 148.0$ (Ar- $C_{\text {ortho }}$ ), 143.1 (Ar- $C_{\text {ipso }}$ ), 126.2 (Ar- $\left.C_{\text {para }}\right), 124.3$ (Ar- $\left.C_{\text {meta }}\right), 55.4\left(\mathrm{CH}_{2}\right), 28.4$ (Dipp- $\left.\mathrm{CH}\right), 25.4$ (Dipp- $\mathrm{CH}_{3}$ ), 24.7 (Dipp- $\mathrm{CH}_{3}$ ). ${ }^{119} \mathrm{Sn} \mathrm{NMR}\left(112 \mathrm{MHz}, 25{ }^{\circ} \mathrm{C}\right.$, $\left.\mathrm{C}_{6} \mathrm{D}_{6}\right): \delta(\mathrm{ppm})-78$ with ${ }^{117} \mathrm{Sn}$ satellites ${ }^{2} J_{\mathrm{SnSn}}=696 \mathrm{~Hz}$.

Analytical data for $\left[\left\{\operatorname{Sn}\left(\mathbf{L}_{\mathbf{1}}\right)(\boldsymbol{\mu} \text {-Se })\right\}_{2}\right]$ (11). Yield: $56 \mathrm{mg}$, $0.049 \mathrm{mmol}, 20 \% .{ }^{1} \mathrm{H}$ NMR $\left(300 \mathrm{MHz}, 25{ }^{\circ} \mathrm{C}, \mathrm{C}_{6} \mathrm{D}_{6}\right): \delta(\mathrm{ppm})$ 7.17-7.07 (m, 6H, Ar- $H$ ), $3.68\left(\mathrm{sep},{ }^{3} J_{\mathrm{HH}}=6.8 \mathrm{~Hz}, 4 \mathrm{H}\right.$, Dipp$\mathrm{CH}$ ), 3.34 (s with unresolved ${ }^{119} \mathrm{Sn}$ and ${ }^{117} \mathrm{Sn}$ satellites ${ }^{3} J_{\mathrm{HSn}} \approx$ $58 \mathrm{~Hz}, 4 \mathrm{H}, \mathrm{CH}_{2}$ ), 1.24 (d, $\left.{ }^{3} \mathrm{~J}_{\mathrm{HH}}=6.8 \mathrm{~Hz}, 12 \mathrm{H}, \mathrm{Dipp}-\mathrm{CH}_{3}\right), 1.21$ $\left(\mathrm{d},{ }^{3} J_{\mathrm{HH}}=6.8 \mathrm{~Hz}, 12 \mathrm{H}, \operatorname{Dipp}-\mathrm{CH}_{3}\right) \cdot{ }^{13} \mathrm{C} \mathrm{NMR}(75.5 \mathrm{MHz}$, $\left.25{ }^{\circ} \mathrm{C}, \mathrm{C}_{6} \mathrm{D}_{6}\right): \delta(\mathrm{ppm}) 148.0$ (Ar- $C_{\text {ortho }}$ ), 143.3 (Ar- $\left.C_{\text {ipso }}\right), 126.2$ (Ar- $\left.C_{\text {para }}\right), 123.8$ (Ar- $\left.C_{\text {meta }}\right), 55.7\left(\mathrm{CH}_{2}\right), 28.5$ (Dipp- $\left.\mathrm{CH}\right), 25.5$ (Dipp- $\mathrm{CH}_{3}$ ), 24.9 (Dipp- $\left.\mathrm{CH}_{3}\right) .{ }^{119} \mathrm{Sn}$ NMR (112 MHz, $25{ }^{\circ} \mathrm{C}$, 
$\left.\mathrm{C}_{6} \mathrm{D}_{6}\right): \delta(\mathrm{ppm})-320$ with ${ }^{77} \mathrm{Se}$ satellites ${ }^{1} J_{\mathrm{SnSe}}=1229 \mathrm{~Hz}$. Elemental analysis calculated for $\mathrm{C}_{52} \mathrm{H}_{76} \mathrm{~N}_{4} \mathrm{Se}_{2} \mathrm{Sn}_{2}$ (\%): C 54.19 H 6.65 N 4.86. Found (\%): C 54.17 H 6.87 N 4.93.

\section{Reactions with MeI}

[Sn(Me)I(L $\left.\left.\mathbf{L}_{1}\right)\right]$ (12). Method A: $6(0.175 \mathrm{~g}, 0.35 \mathrm{mmol})$ was dissolved in $\mathrm{Et}_{2} \mathrm{O}\left(10 \mathrm{~cm}^{3}\right)$ and $\mathrm{MeI}\left(0.057 \mathrm{~cm}^{3}, 0.91 \mathrm{mmol}\right)$ was added. The solution was stirred for $2.5 \mathrm{~h}$, filtered and $n$-hexane $\left(6 \mathrm{~cm}^{3}\right)$ was added before concentration of the solution under reduced pressure to $c a .3 \mathrm{~cm}^{3}$. Crystalline material was obtained after placement at $4{ }^{\circ} \mathrm{C}$ overnight $(0.10 \mathrm{~g}$, $0.16 \mathrm{mmol}, 46 \%)$.

$\left[\operatorname{Sn}(\mathrm{Me}) \mathrm{I}\left(\mathrm{L}_{1}\right)\right]$ (12). Method $\mathrm{B}$, one pot reaction from the diamine: To a $0{ }^{\circ} \mathrm{C}$ solution of $\left(\mathrm{L}_{1}\right) \mathrm{H}_{2}(1.272 \mathrm{~g}, 3.34 \mathrm{mmol})$ dissolved in $\mathrm{Et}_{2} \mathrm{O}\left(40 \mathrm{~cm}^{3}\right)$ was added ${ }^{n} \mathrm{BuLi}$ (1.6 $\mathrm{M}$ in $n$-hexane, $4.3 \mathrm{~cm}^{3}, 6.68 \mathrm{mmol}$ ) which was allowed to stir at room temperature overnight. This was then added to a $-78^{\circ} \mathrm{C}$ suspension of $\mathrm{SnCl}_{2}(0.634 \mathrm{~g}, 3.34 \mathrm{mmol})$ in $\mathrm{Et}_{2} \mathrm{O}\left(20 \mathrm{~cm}^{3}\right)$ which was then allowed to warm to room temperature and stirred for $3 \mathrm{~h}$. The solution was filtered followed by addition of MeI $\left(0.54 \mathrm{~cm}^{3}\right.$, $8.69 \mathrm{mmol}$ ) and the reaction stirred overnight at room temperature. The solution was evaporated to dryness and the residue was extracted with $n$-hexane $\left(40 \mathrm{~cm}^{3}\right)$, filtered and the clear, pale yellow solution was reduced in volume to $c a$. $10 \mathrm{~cm}^{3}$. Upon cooling, pale yellow crystals formed $(1.366 \mathrm{~g}$, $2.14 \mathrm{mmol}, 64 \%$ yield).

Analytical data for $12 .{ }^{1} \mathrm{H}$ NMR $\left(300 \mathrm{MHz}, 25{ }^{\circ} \mathrm{C}, \mathrm{C}_{6} \mathrm{D}_{6}\right)$ : $\delta(\mathrm{ppm}) 7.20-7.17(\mathrm{~m}, 6 \mathrm{H}, \mathrm{Ar}-H), 4.15\left(\mathrm{sep},{ }^{3} J_{\mathrm{HH}}=7.0 \mathrm{~Hz}, 2 \mathrm{H}\right.$ Dipp-CH), 3.60 (m, 4H, overlapping Dipp-CH and $\mathrm{NC}(\mathrm{H}) H-\mathrm{C}(\mathrm{H})-$ $H \mathrm{~N}), 3.32(\mathrm{~m}, 2 \mathrm{H}, \mathrm{NC}(H) \mathrm{H}-\mathrm{C}(H) \mathrm{HN}), 1.51\left(\mathrm{~d},{ }^{3} J_{\mathrm{HH}}=7.0,6 \mathrm{H}\right.$, Dipp-CH $\left.H_{3}\right), 1.32\left(\mathrm{~d},{ }^{3} J_{\mathrm{HH}}=6.8,6 \mathrm{H}, \operatorname{Dipp}-\mathrm{CH}_{3}\right), 1.27\left(\mathrm{~d},{ }^{3} J_{\mathrm{HH}}=\right.$ 6.8, 6H, Dipp-CH $\mathrm{CH}_{3}, 1.14$ (d, $\left.{ }^{3} \mathrm{~J}_{\mathrm{HH}}=7.0,6 \mathrm{H}, \mathrm{Dipp}-\mathrm{CH}_{3}\right), 0.59$ (s with ${ }^{119} \mathrm{Sn}$ and ${ }^{117} \mathrm{Sn}$ satellites ${ }^{2} J_{\mathrm{H}(117) \mathrm{Sn}}=77.5 \mathrm{~Hz}^{2} J_{\mathrm{H}(119) \mathrm{Sn}}=$ $\left.81.0 \mathrm{~Hz}, 3 \mathrm{H}, \mathrm{Sn}-\mathrm{CH}_{3}\right) .{ }^{13} \mathrm{C} \mathrm{NMR}\left(75.4 \mathrm{MHz}, 25{ }^{\circ} \mathrm{C}, \mathrm{C}_{6} \mathrm{D}_{6}\right)$ : $\delta(\mathrm{ppm}) 149.6(\mathrm{Ar}-C), 147.4(\mathrm{Ar}-C), 144.6(\mathrm{Ar}-\mathrm{C}), 126.1$ (Ar-C), 124.7 (Ar- $C$ ), 123.5 (Ar- $C$ ), $56.7\left(\mathrm{CH}_{2} \mathrm{NSn}\right), 28.328 .126 .025 .8$ $25.723 .9\left({ }^{\mathrm{i}} \mathrm{Pr}-\mathrm{C}\right), 6.7\left(\mathrm{Sn}-\mathrm{CH}_{3}\right) .{ }^{119} \mathrm{Sn} \mathrm{NMR}\left(111.9 \mathrm{MHz}, 25{ }^{\circ} \mathrm{C}\right.$, $\left.\mathrm{C}_{6} \mathrm{D}_{6}\right): \delta(\mathrm{ppm})$-151. Elemental analysis calculated for $\mathrm{C}_{27} \mathrm{H}_{41} \mathrm{IN}_{2} \mathrm{Sn}$ (\%): C $50.73 \mathrm{H} 6.47 \mathrm{~N} 4.38$. Found (\%): C $51.40 \mathrm{H}$ $6.95 \mathrm{~N} 4.47$.

[Sn(Me)I(L $\left.\left.\mathbf{L}_{2}\right)\right]$ (13). Method A: $7(0.827 \mathrm{~g}, 1.62 \mathrm{mmol})$ and MeI $\left(0.26 \mathrm{~cm}^{3}, 4.21 \mathrm{mmol}\right)$ were reacted together. Very pale yellow crystals were isolated after crystallisation at $4{ }^{\circ} \mathrm{C}$ overnight (0.53 g, $0.81 \mathrm{mmol}, 50 \%)$.

$\left[\operatorname{Sn}(\mathbf{M e}) \mathbf{I}\left(\mathbf{L}_{2}\right)\right](13)$. Method B: The diamine $\left(\mathrm{L}_{2}\right) \mathrm{H}_{2}(1.07 \mathrm{~g}$, $2.7 \mathrm{mmol})$ was dilithiated and reacted with $\mathrm{SnCl}_{2}(0.512 \mathrm{~g}$, $2.7 \mathrm{mmol})$ according to method B. MeI $\left(0.6 \mathrm{~cm}^{3}, 10 \mathrm{mmol}\right)$ was added and pale yellow crystals were isolated after crystallization at $-20{ }^{\circ} \mathrm{C}(1.08 \mathrm{~g}, 1.65 \mathrm{mmol}, 61 \%$ yield $)$.

Analytical data for $13 .{ }^{1} \mathrm{H}$ NMR $\left(300 \mathrm{MHz}, 25{ }^{\circ} \mathrm{C}, \mathrm{C}_{6} \mathrm{D}_{6}\right)$ : $\delta(\mathrm{ppm}) 7.17-7.05(\mathrm{~m}, 6 \mathrm{H}, \mathrm{Ar}-H), 4.06\left(\mathrm{sep},{ }^{3} J_{\mathrm{HH}}=6.8 \mathrm{~Hz}, 2 \mathrm{H}\right.$ Dipp-CH), 3.79 (sep, ${ }^{3} J_{\mathrm{HH}}=7.0 \mathrm{~Hz}, 2 \mathrm{H}$ Dipp-CH) 3.57-3.34 (m, $4 \mathrm{H}, \mathrm{CH}_{2}\left(\mathrm{CH}_{2} \mathrm{NDipp}\right), 2.65-2.51$ (m, $1 \mathrm{H}, \mathrm{HCH}\left(\mathrm{CH}_{2} \mathrm{NDipp}_{2}\right)$, 1.87-1.79 (m, $\left.1 \mathrm{H}, \mathrm{HCH}\left(\mathrm{CH}_{2} \mathrm{NDipp}\right)_{2}\right), 1.47\left(\mathrm{~d},{ }^{3} J_{\mathrm{HH}}=6.8 \mathrm{~Hz}\right.$, $6 \mathrm{H}$, Dipp- $\left.\mathrm{CH}_{3}\right), 1.33$ (d, $\left.{ }^{3} J_{\mathrm{HH}}=7.0 \mathrm{~Hz}, 6 \mathrm{H}, \mathrm{Dipp}-\mathrm{CH}_{3}\right), 1.29$ $\left(\mathrm{d},{ }^{3} \mathrm{~J}_{\mathrm{HH}}=6.8 \mathrm{~Hz}, 6 \mathrm{H}\right.$, Dipp-CH$), 1.21\left(\mathrm{~d},{ }^{3} \mathrm{~J}_{\mathrm{HH}}=7.0 \mathrm{~Hz}, 6 \mathrm{H}\right.$,
Dipp- $\mathrm{CH}_{3}$ ), 0.30 (s with ${ }^{119} \mathrm{Sn}$ and ${ }^{117} \mathrm{Sn}$ satellites ${ }^{2} J_{\mathrm{H}(117) \mathrm{Sn}}=$ $\left.74.9 \mathrm{~Hz}^{2} \mathrm{~J}_{\mathrm{H}(119) \mathrm{Sn}}=78.2 \mathrm{~Hz}, 3 \mathrm{H}, \mathrm{Sn}-\mathrm{CH}_{3}\right) .{ }^{13} \mathrm{C} \mathrm{NMR}(75.4 \mathrm{MHz}$, $\left.25{ }^{\circ} \mathrm{C}, \mathrm{C}_{6} \mathrm{D}_{6}\right): \delta(\mathrm{ppm}) 149.7$ (Ar- $C$ ), 147.8 (Ar- $C$ ), $145.3(\mathrm{Ar}-C)$, 126.5 (Ar-C), $125.2(\mathrm{Ar}-\mathrm{C}), 123.5(\mathrm{Ar}-\mathrm{C}), 57.3\left(\mathrm{CH}_{2}\right), 37.0\left(\mathrm{CH}_{2}\right)$ $28.428 .027 .026 .725 .6,23.7\left({ }^{\mathrm{i}} \mathrm{Pr}-\mathrm{C}\right), 2.2\left(\mathrm{Sn}-\mathrm{CH}_{3}\right) .{ }^{119} \mathrm{Sn}$ NMR (111.9 MHz, $\left.25{ }^{\circ} \mathrm{C}, \mathrm{C}_{6} \mathrm{D}_{6}\right): \delta(\mathrm{ppm})-185$. Mass spectrometry (E.I.): $m / z 654\left(\mathbf{M}^{+}\right), 639\left(\mathbf{M}^{+}-\mathrm{CH}_{3}\right), 527\left(\mathbf{M}^{+}-\mathrm{I}\right), 512$ $\left(\mathrm{M}^{+}-\mathrm{CH}_{3}\right.$ and $\left.\mathrm{I}\right)$ all with correct isotope distributions.

[Sn(Me)I $\left.\left(\mathbf{L}_{3}\right)\right]$ (14). Method B: The diamine $\left(\mathrm{L}_{3}\right) \mathrm{H}_{2}(0.965 \mathrm{~g}$, $1.8 \mathrm{mmol})$ was dilithiated and reacted with $\mathrm{SnCl}_{2}(0.342 \mathrm{~g}$, $1.8 \mathrm{mmol})$ according to method B. MeI $\left(0.46 \mathrm{~cm}^{3}, 7.2 \mathrm{mmol}\right)$ was added and colourless crystals were isolated after storage at $-20{ }^{\circ} \mathrm{C}$ (0.532 g, $0.67 \mathrm{mmol}, 37 \%$ overall yield). ${ }^{1} \mathrm{H}$ NMR (300 MHz, $\left.25{ }^{\circ} \mathrm{C}, \mathrm{C}_{6} \mathrm{D}_{6}\right): \delta(\mathrm{ppm}) 8.04(\mathrm{~m}, 2 \mathrm{H}, \mathrm{Ar}-H), 7.17-6.97$ $(\mathrm{m}, 12 \mathrm{H}, \operatorname{Ar}-H), 6.84(\mathrm{~m}, 2 \mathrm{H}, \operatorname{Ar}-H), 4.16\left(\mathrm{sep},{ }^{3} J_{\mathrm{HH}}=6.8 \mathrm{~Hz}\right.$, 4H, Dipp-CH), 1.27 (d, ${ }^{3} J_{\mathrm{HH}}=6.8 \mathrm{~Hz}, 12 \mathrm{H}$, Dipp-CH $\mathrm{C}_{3}$ ), 0.99 (s, with ${ }^{119} \mathrm{Sn}$ and ${ }^{117} \mathrm{Sn}$ satellites ${ }^{2} J_{\mathrm{H}(119) \mathrm{Sn}}=74.6 \mathrm{~Hz},{ }^{2} J_{\mathrm{H}(117) \mathrm{Sn}}=$ $\left.71.6 \mathrm{~Hz}, \mathrm{Sn}-\mathrm{CH}_{3}\right), 0.78$ (d, $\left.{ }^{3} J_{\mathrm{HH}}=6.8 \mathrm{~Hz}\right) .{ }^{13} \mathrm{C} \mathrm{NMR}(75.5 \mathrm{MHz}$, $\left.25{ }^{\circ} \mathrm{C}, \mathrm{C}_{6} \mathrm{D}_{6}\right): \delta(\mathrm{ppm}) 147.1,140.7,137.5,135.9,135.2,134.2$, 129.8, 127.4, 127.3, 124.9, 124.1 (collection of Ar-C), 28.225 .4 $24.9\left({ }^{\mathrm{i}} \mathrm{Pr}-\mathrm{C}\right), 16.1\left(\mathrm{Sn}-\mathrm{CH}_{3}\right) .{ }^{119} \mathrm{Sn}$ NMR (111.9 MHz, $\left.25^{\circ} \mathrm{C}, \mathrm{C}_{6} \mathrm{D}_{6}\right)$ : $\delta(\mathrm{ppm})-129 .{ }^{29} \mathrm{Si}$ NMR $\left(59.6 \mathrm{MHz}, 25{ }^{\circ} \mathrm{C}, \mathrm{C}_{6} \mathrm{D}_{6}\right): \delta(\mathrm{ppm})-17$. Elemental analysis calculated for $\mathrm{C}_{37} \mathrm{H}_{47} \mathrm{IN}_{2} \mathrm{SiSn}$ (\%): C 56.01 H 5.97 N 3.53. Found (\%): C 56.92 H 6.41 N 3.76.

[Sn(Me)I(L $\left.\left.\mathbf{L}_{4}\right)\right](\mathbf{1 5})$. Method A: $9(0.380 \mathrm{~g}, 0.70 \mathrm{mmol})$ and MeI $\left(0.17 \mathrm{~cm}^{3}, 2.8 \mathrm{mmol}\right)$ were reacted together. Colourless crystals were isolated after storage at $-20{ }^{\circ} \mathrm{C}$ overnight $(0.30 \mathrm{~g}$, $0.44 \mathrm{mmol}, 62 \%) .{ }^{1} \mathrm{H}$ NMR $\left(300 \mathrm{MHz}, 25{ }^{\circ} \mathrm{C}, \mathrm{C}_{6} \mathrm{D}_{6}\right): \delta(\mathrm{ppm})$ 7.18-7.19 (m, Ar- $H$ ), 3.96 (sep, ${ }^{3} J_{\mathrm{HH}}=7.0 \mathrm{~Hz}, 2 \mathrm{H}$ Dipp-CH), $3.61\left(\mathrm{sep},{ }^{3} J_{\mathrm{HH}}=7.0 \mathrm{~Hz}, 2 \mathrm{H}\right.$, Dipp-CH), $3.44\left(\mathrm{~m}, 4 \mathrm{H}, \mathrm{O}-\mathrm{CH}_{2}\right)$, $3.36(\mathrm{~m}, 2 \mathrm{H}, \mathrm{N}-\mathrm{C}(H) \mathrm{H}), 3.05(\mathrm{~m}, 2 \mathrm{H}, \mathrm{N}-\mathrm{C}(\mathrm{H}) H), 1.44\left(\mathrm{~d},{ }^{3} J_{\mathrm{HH}}=\right.$ $7.0 \mathrm{~Hz}$, Dipp-CH$\left.{ }_{3}\right), 1.33$ (d, ${ }^{3} \mathrm{~J}_{\mathrm{HH}}=7.0 \mathrm{~Hz}$, Dipp-CH$\left.{ }_{3}\right), 1.31$ $\left(\mathrm{d},{ }^{3} J_{\mathrm{HH}}=7.0 \mathrm{~Hz}\right.$, Dipp-CH$), 1.22\left(\mathrm{~d},{ }^{3} J_{\mathrm{HH}}=7.0 \mathrm{~Hz}\right.$, Dipp-CH $\mathrm{CH}_{3}$ ), 0.56 (very br. s, Sn- $\mathrm{CH}_{3}$ ). ${ }^{13} \mathrm{C}$ NMR (75.5 MHz, $25{ }^{\circ} \mathrm{C}, \mathrm{C}_{6} \mathrm{D}_{6}$ ): $\delta(\mathrm{ppm}) 149.9$ (Ar- $C$ ), 148.5 (Ar- $\left.C_{\text {ortho }}\right), 146.9$ (Ar- $\left.C_{\text {ortho }}\right), 126.6$ $\left(\mathrm{Ar}-C_{\text {para }}\right), 124.9\left(\mathrm{Ar}-C_{\text {meta }}\right), 124.0\left(\mathrm{Ar}-C_{\text {meta }}\right), 71.2\left(\mathrm{O}-\mathrm{CH}_{2}\right), 52.3$ $\left(\mathrm{N}-\mathrm{CH}_{2}\right), 28.9\left(\right.$ Dipp- $\left.\mathrm{CH}_{3}\right), 28.7$ (Dipp- $\left.\mathrm{CH}_{3}\right), 26.3\left(\right.$ Dipp- $\left.\mathrm{CH}_{3}\right)$, 26.2 (Dipp- $\mathrm{CH}_{3}$ ), 25.5 (Dipp-CH), 24.1 (Dipp-CH), 1.7 ( $\left.\mathrm{Sn}-\mathrm{CH}_{3}\right)$. ${ }^{119} \mathrm{Sn}$ NMR $\left(111.9 \mathrm{MHz}, 25{ }^{\circ} \mathrm{C}, \mathrm{C}_{6} \mathrm{D}_{6}\right): \delta(\mathrm{ppm})-220$ (very br. s). Elemental analysis calculated for $\mathrm{C}_{29} \mathrm{H}_{45} \mathrm{IN}_{2} \mathrm{OSn}(\%)$ : C 50.98 H 6.64 N 4.10. Found (\%): C 51.18 H 7.03 N 4.13.

\section{General method for the formation of tin triflates}

The tin iodide ( 1 equiv.) was dissolved in $\mathrm{CH}_{2} \mathrm{Cl}_{2}$ or toluene $\left(10 \mathrm{~cm}^{3}\right)$, cooled to $-78{ }^{\circ} \mathrm{C}$ and AgOTf (1 equiv.) was added. The reaction was stirred for $16 \mathrm{~h}$, filtered and then the product was crystallised from the minimum volume of toluene or ether.

[Sn(Me)OTf(L $\left.\left.\mathbf{L}_{\mathbf{1}}\right)\right]$ (16). $12(0.50 \mathrm{~g}, 0.78 \mathrm{mmol})$ in $\mathrm{CH}_{2} \mathrm{Cl}_{2}$ $\left(20 \mathrm{~cm}^{3}\right)$ was reacted with AgOTf $(0.201 \mathrm{~g}, 0.78 \mathrm{mmol})$. The reaction mixture was evaporated to dryness and extracted with $\mathrm{CH}_{2} \mathrm{Cl}_{2}\left(20 \mathrm{~cm}^{3}\right)$, filtered and the product crystallised from $\mathrm{Et}_{2} \mathrm{O}$ as colourless crystals at room temperature $(0.217 \mathrm{~g}$, $0.328 \mathrm{mmol}, 42 \%) .{ }^{1} \mathrm{H}$ NMR (300 $\left.\mathrm{MHz}, 25{ }^{\circ} \mathrm{C}, \mathrm{CD}_{2} \mathrm{Cl}_{2}\right)$ : $\delta(\mathrm{ppm}) 7.17-7.13(\mathrm{~m}, 6 \mathrm{H}, \operatorname{Ar}-H), 3.85\left(\mathrm{sep},{ }^{3} J_{\mathrm{HH}}=7.0,2 \mathrm{H}\right.$, Dipp-CH), 3.60 (sep, ${ }^{3} J_{\mathrm{HH}}=6.8 \mathrm{~Hz}, 2 \mathrm{H}$, Dipp-CH), $3.55(\mathrm{~m}, 2 \mathrm{H}$, 
$\mathrm{C}(H) \mathrm{HN}), 3.37(\mathrm{~m}, 2 \mathrm{H}, \mathrm{C}(\mathrm{H}) H \mathrm{~N}), 1.29$ (overlapping d, Dipp$\left.\mathrm{CH}_{3}\right), 1.25$ (s, Sn-CH$\left.\left.{ }_{3}\right) .{ }^{119} \mathrm{Sn} \mathrm{NMR} \mathrm{(111.9} \mathrm{MHz,} 25^{\circ} \mathrm{C}, \mathrm{CD}_{2} \mathrm{Cl}_{2}\right)$ : $\delta(\mathrm{ppm})-155 .{ }^{19} \mathrm{~F}$ NMR $\left(282.7 \mathrm{MHz}, 25{ }^{\circ} \mathrm{C}, \mathrm{CD}_{2} \mathrm{Cl}_{2}\right): \delta(\mathrm{ppm})$ -78.0. cf. AgOTf ${ }^{19} \mathrm{~F}$ NMR (282.7 MHz, $\left.25^{\circ} \mathrm{C}, \mathrm{CD}_{2} \mathrm{Cl}_{2}\right): \delta(\mathrm{ppm})$ $-111.8 \mathrm{ppm}$.

[Sn(Me)OTf( $\left.\left.\mathbf{L}_{2}\right)\right]$ (17). $13(0.217 \mathrm{~g}, 0.332 \mathrm{mmol})$ in toluene $\left(10 \mathrm{~cm}^{3}\right)$ was reacted with AgOTf ( $85 \mathrm{mg}, 0.33 \mathrm{mmol}$ ) and colourless crystals were grown from toluene at $-20{ }^{\circ} \mathrm{C}$ for 3 days (0.128 g, $0.19 \mathrm{mmol}, 57 \%) .{ }^{1} \mathrm{H}$ NMR (300 MHz, $\left.25^{\circ} \mathrm{C}, \mathrm{C}_{6} \mathrm{D}_{6}\right)$ : $\delta(\mathrm{ppm}) 7.23-7.04(\mathrm{~m}, 6 \mathrm{H}, \mathrm{Ar}-H), 3.95\left(\mathrm{sep},{ }^{3} \mathrm{~J}_{\mathrm{HH}}=6.6 \mathrm{~Hz}, 2 \mathrm{H}\right.$, Dipp-CH $\left.H_{3}\right), 3.46$ (sep, ${ }^{3} J_{\mathrm{HH}}=6.6 \mathrm{~Hz}, 2 \mathrm{H}$, Dipp-CH $\mathrm{CH}_{3}$ ), 3.28-3.19 $\left(\mathrm{m}, \quad 4 \mathrm{H}, \quad \mathrm{CH}_{2} \mathrm{~N}\right), \quad 2.32-2.27\left(\mathrm{~m}, \quad 1 \mathrm{H}, \quad \mathrm{NCH}_{2} \mathrm{C}(H) \mathrm{HCH}_{2} \mathrm{~N}\right)$, 1.71-1.65 (m, 1H, $\left.\mathrm{NCH}_{2} \mathrm{C}(\mathrm{H}) \mathrm{HCH}_{2} \mathrm{~N}\right), 1.55\left(\mathrm{~d},{ }^{3} \mathrm{~J}_{\mathrm{HH}}=6.6 \mathrm{~Hz}\right.$, 6H, Dipp- $\mathrm{CH}_{3}$ ), 1.33 (d, $\left.{ }^{3} J_{\mathrm{HH}}=6.6 \mathrm{~Hz}, 6 \mathrm{H}, \mathrm{Dipp}-\mathrm{CH}_{3}\right), 1.28$ $\left(\mathrm{d},{ }^{3} J_{\mathrm{HH}}=6.6 \mathrm{~Hz}, 6 \mathrm{H}, \operatorname{Dipp}-\mathrm{CH}_{3}\right), 1.13\left(\mathrm{~d},{ }^{3} J_{\mathrm{HH}}=6.6 \mathrm{~Hz}, 6 \mathrm{H}\right.$, Dipp-C $H_{3}$ ), 0.41 (s with ${ }^{119} \mathrm{Sn}$ and ${ }^{117} \mathrm{Sn}$ satellites ${ }^{2} J_{\mathrm{H}(119) \mathrm{Sn}}=$ $\left.86.9 \mathrm{~Hz},{ }^{2} J_{\mathrm{H}(117) \mathrm{Sn}}=82.9 \mathrm{~Hz}, 3 \mathrm{H}, \mathrm{Sn}-\mathrm{CH}_{3}\right) .{ }^{13} \mathrm{C}$ NMR (75.4 MHz, $\left.25{ }^{\circ} \mathrm{C}, \mathrm{C}_{6} \mathrm{D}_{6}\right): \delta(\mathrm{ppm}) 149.7,146.6,143.9,127.4$, 125.6, 123.8 (collection of Ar-C), 119.9 (q, $\left.\mathrm{CF}_{3}\right), 57.8\left(\mathrm{CH}_{2} \mathrm{~N}\right)$, $32.8\left(\mathrm{NCH}_{2} \mathrm{CH}_{2} \mathrm{CH}_{2} \mathrm{~N}\right.$ ), 29.2 (Dipp-CH), 28.0 (Dipp- $\mathrm{CH}$ ), 26.9 (Dipp- $\left.\mathrm{CH}_{3}\right), 26.1$ (Dipp- $\left.\mathrm{CH}_{3}\right), 25.1$ (Dipp- $\left.\mathrm{CH}_{3}\right), 24.4$ (Dipp$\mathrm{CH}_{3}$ ), -3.0 (s with ${ }^{119} \mathrm{Sn}$ and ${ }^{117} \mathrm{Sn}$ satellites ${ }^{1} \mathrm{~J}_{\mathrm{C}(119) \mathrm{Sn}}=653 \mathrm{~Hz}$, $\left.{ }^{1} J_{\mathrm{C}(117) \mathrm{Sn}}=624 \mathrm{~Hz}, \mathrm{Sn}-\mathrm{CH}_{3}\right) \cdot{ }^{119} \mathrm{Sn} \mathrm{NMR}\left(111.9 \mathrm{MHz}, 25{ }^{\circ} \mathrm{C}\right.$, $\left.\mathrm{C}_{6} \mathrm{D}_{6}\right): \delta(\mathrm{ppm})-95 .{ }^{19} \mathrm{~F}$ NMR $\left(282.7 \mathrm{MHz}, 25{ }^{\circ} \mathrm{C}, \mathrm{C}_{6} \mathrm{D}_{6}\right)$ : $\delta(\mathrm{ppm})$-77.1. Elemental analysis calculated for (\%): C 51.57 H 6.42 N 4.15. Found (\%): C 52.89 H 6.56 N 4.22.

[Sn(Me)OTf( $\left.\left(\mathbf{L}_{3}\right)\right]$ (18). $14(0.258 \mathrm{~g}, 0.325 \mathrm{mmol})$ in toluene $\left(10 \mathrm{~cm}^{3}\right)$ was reacted with AgOTf ( $\left.84 \mathrm{mg}, 0.325 \mathrm{mmol}\right)$ and colourless crystals were obtained from toluene after storage at $-20{ }^{\circ} \mathrm{C}(77 \mathrm{mg})$. Although the molecular structure of the desired product was determined, multi-nuclear NMR spectroscopy showed that there were multiple products formed in the reaction that could not be separated.

[Sn(Me)OTf(L $\left.\left.\mathbf{L}_{4}\right)\right]$ (19). $15(0.210 \mathrm{~g}, 0.307 \mathrm{mmol})$ in toluene $\left(10 \mathrm{~cm}^{3}\right)$ at $-78{ }^{\circ} \mathrm{C}$ was reacted with AgOTf $(79 \mathrm{mg}$, $0.307 \mathrm{mmol}$ ) and colourless crystals were obtained from toluene after storage at $-20{ }^{\circ} \mathrm{C}(89 \mathrm{mg}, 0.126 \mathrm{mmol}, 41 \%)$. ${ }^{1} \mathrm{H}$ NMR $\left(300 \mathrm{MHz}, 25{ }^{\circ} \mathrm{C}, \mathrm{C}_{6} \mathrm{D}_{6}\right): \delta(\mathrm{ppm}) 7.19-7.05(\mathrm{~m}, 6 \mathrm{H}$, $\operatorname{Ar}-H$ ), 3.91 (app. sep, ${ }^{3} J_{\mathrm{HH}}=6.6$ and $6.8 \mathrm{~Hz}, 2 \mathrm{H}$, Dipp-CH), 3.78 (br. s, 2H, $\mathrm{CH}_{2}$ ), 3.42 (br. m, 4H, Dipp-CH and $\mathrm{CH}_{2}$ ), 3.18 (br. m, 2H, $\mathrm{CH}_{2}$ ), $2.99\left(\mathrm{~m}, 2 \mathrm{H}, \mathrm{CH}_{2}\right.$ ), 1.39 (d, ${ }^{3} J_{\mathrm{HH}}=6.6 \mathrm{~Hz}$, $12 \mathrm{H}$, Dipp-C $\mathrm{H}_{3}$ ), 1.23 (br. d, ${ }^{3} J_{\mathrm{HH}} \approx 6.2 \mathrm{~Hz}, 6 \mathrm{H}, \mathrm{Dipp}-\mathrm{CH}_{3}$ ), 1.18 (d, ${ }^{3} \mathrm{JHH}_{\mathrm{HH}}=6.8 \mathrm{~Hz}, 6 \mathrm{H}, \mathrm{Dipp}-\mathrm{CH}_{3}$ ), -0.18 (br. s, $\left.3 \mathrm{H}, \mathrm{Sn}-\mathrm{CH}_{3}\right) \cdot{ }^{13} \mathrm{C}$ NMR (75.4 MHz, $\left.25{ }^{\circ} \mathrm{C}, \mathrm{C}_{6} \mathrm{D}_{6}\right): \delta$ (ppm) 149.4, 147.8, 144.1, 127.2, 125.1, 123.8 (collection of $\mathrm{Ar}-C$ ), 69.6 (bs, $\mathrm{OCH}_{2}$ ), 50.9 $\left(\mathrm{NCH}_{2}\right), 28.9$ (Dipp-CH), 28.0 (Dipp-CH), 26.4 (Dipp- $\left.\mathrm{CH}_{3}\right), 26.2$ (Dipp- $\left.\mathrm{CH}_{3}\right), 24.3$ (Dipp- $\left.\mathrm{CH}_{3}\right), 24.0\left(\right.$ Dipp- $\left.\mathrm{CH}_{3}\right) .{ }^{119} \mathrm{Sn}$ NMR (111.9 MHz, $\left.25{ }^{\circ} \mathrm{C}, \mathrm{C}_{6} \mathrm{D}_{6}\right): \delta(\mathrm{ppm})-152 .{ }^{19} \mathrm{~F}$ NMR $(282.7 \mathrm{MHz}$, $\left.25{ }^{\circ} \mathrm{C}, \mathrm{C}_{6} \mathrm{D}_{6}\right): \delta(\mathrm{ppm})-76.8$. Elemental analysis calculated for $\mathrm{C}_{30} \mathrm{H}_{45} \mathrm{~F}_{3} \mathrm{~N}_{2} \mathrm{O}_{4} \mathrm{SSn}$ (\%): C $51.08 \mathrm{H} 6.43 \mathrm{~N}$ 3.97. Found (\%): C 51.08 H 6.38 N 4.19 .

\section{X-ray crystallographic studies}

Crystals suitable for X-ray crystallographic analysis were grown from saturated $n$-hexane solution $(3,4,5$ monoclinic, 10-13, 15), saturated toluene solution $(1,2,5$ triclinic, $14,17-19)$ or saturated diethyl ether solution (16). The crystals were covered in an inert oil and then transferred to the cold stream of the diffractometer. Experiments were performed using either a Bruker-AXS SMART, SMART-APEX three-circle diffractometer ${ }^{48}$ using Mo-K $\alpha$ radiation $(\lambda=0.71073 \AA)$. Intensities were integrated $^{49}$ from several series of exposures, each exposure covering $0.3^{\circ}$ in $\omega$. Data for 18 were collected using $\mathrm{Cu}-\mathrm{K} \alpha$ radiation $(\lambda=1.54184 \AA)$ on an Oxford diffraction Gemini diffractometer. Absorption corrections were applied based on multiple and symmetry-equivalent measurements. ${ }^{50}$ The structures were solved by direct methods and refined by least-squares on weighted $F^{2}$ values for all reflections. ${ }^{51}$ All non-hydrogen atoms were assigned anisotropic displacement parameters and refined without positional constraints. Hydrogen atoms were constrained to ideal geometries and refined with fixed isotropic displacement parameters except for the $\mathrm{N}-\mathrm{H}$ hydrogen atoms in $\mathbf{5}$ monoclinic and $\mathbf{5}$ triclinic which were located in the Fourier difference map and were refined with fixed isotropic parameters. Refinement proceeded smoothly to give the residuals shown in Table ESI $1 \dagger$ and final $R_{1}$ values $(I>2 \sigma)$ range from 1.9 to $9.0 \%$. Complex neutral-atom scattering factors were used. ${ }^{52}$ The structure of 5 monoclinic showed disorder of one carbon atom in the ligand back bone that was refined over two sites with site occupancy factors of 0.51 and 0.49. The structures of $\mathbf{5}$ triclinic and $\mathbf{1 3}$ showed disorder in one isopropyl group which were modelled over two sites with sites occupancy factors of $0.94: 0.06$ and $0.52: 0.48 .15$ showed disorder in the iodide and methyl groups with site occupancy factors of 0.85/0.15. CCDC reference numbers: 1027507-1027522.

\section{Conclusions}

Dimethyltindiamide compounds with chelating ligands are readily synthesised using a salt metathesis strategy from the dilithiated diamide ligand precursors and $\mathrm{Me}_{2} \mathrm{SnCl}_{2}$. Attempts to make dichlorotindiamide compounds with chelating amide ligands showed an unexpected dependence on the ligand with the $\mathrm{C}_{2}$ linked diamine only yielding a trichlorotinamide/amine compound via both an oxidative synthetic route from an $\mathrm{N}$-heterocyclic stannylene or from reaction of the diamine with $\mathrm{SnCl}_{4}$ and $\mathrm{NEt}_{3}$. However, reaction of the $\mathrm{C}_{3}$ linked diamine with $\mathrm{SnCl}_{4}$ and $\mathrm{NEt}_{3}$ furnished the desired dichlorotindiamide. Saturated N-heterocyclic stannylenes were found to readily undergo oxidative addition reactions with $\mathrm{S}$ and Se (E) yielding chalcogen-bridged four-membered $\mathrm{Sn}_{2} \mathrm{E}_{2}$ ring systems, and with MeI to give crystalline tin(Iv) products. These compounds were found to be suitable starting materials for further reactivity as demonstrated by their reaction with AgOTf to generate the corresponding tin triflates.

\section{Acknowledgements}

The authors would like to thank the University of Bristol for funding. S.M.M. thanks Heriot-Watt University, The Royal 
Society (Research grant: RG130436) and the EPSRC (First grant: EP/M004767/1) for current funding.

\section{Notes and references}

1 R. W. Chorley, P. B. Hitchock, B. S. Jolly, M. F. Lappert and G. A. Lawless, J. Chem. Soc., Chem. Commun., 1991, 1302.

2 M. F. Lappert, Main Group Met. Chem., 1994, 17, 183.

3 B. Wrackmeyer, G. Kehr, H. Zhou and S. Ali, Inorg. Chim. Acta, 1992, 197, 129.

4 B. Wrackmeyer, W. Milius, H. E. Maisel, H. Vollrath and M. Herberhold, Z. Anorg. Allg. Chem., 2003, 629, 1169.

5 C. Lehnert, J. Wagler, E. Kroke and G. Roewer, Khim. Geterotsikl. Soedin., 2006, 1845.

6 M. Asay, C. Jones and M. Driess, Chem. Rev., 2011, 111, 354.

7 M. F. Lappert, M. C. Misra, M. Onyszchuk, R. S. Rowe, P. P. Power and M. J. Slade, J. Organomet. Chem., 1987, 330, 31.

8 M. Veith and A. Muller, J. Organomet. Chem., 1988, 342, 295.

9 C. Eaborn, M. S. Hill, P. B. Hitchcock, D. Patel, J. D. Smith and S. B. Zhang, Organometallics, 2000, 19, 49.

10 A. Kavara, K. D. Cousineau, A. D. Rohr, J. W. Kampf and M. A. B. Holl, Organometallics, 2008, 27, 1041.

11 J. D. Cotton, P. J. Davidson and M. F. Lappert, J. Chem. Soc., Dalton Trans., 1976, 2275.

12 H. Jing, S. K. Edulji, J. M. Gibbs, C. L. Stern, H. Zhou and S. T. Nguyen, Inorg. Chem., 2004, 43, 4315.

13 J. Jastrzebski, P. A. Vanderschaaf, J. Boersma, G. Vankoten, M. Dewit, Y. F. Wang, D. Heijdenrijk and C. H. Stam, J. Organomet. Chem., 1991, 407, 301.

14 N. Tokitoh and R. Okazaki, Coord. Chem. Rev., 2000, 210, 251.

15 M. Saito, N. Tokitoh and R. Okazaki, J. Am. Chem. Soc., 2004, 126, 15572.

16 M. Saito, N. Tokitoh and R. Okazaki, J. Am. Chem. Soc., 1997, 119, 11124.

17 T. Tajima, N. Takeda, T. Sasamori and N. Tokitoh, Organometallics, 2006, 25, 3552.

18 P. P. Power, Chem. Rev., 1999, 99, 3463.

19 T. Chivers and D. J. Eisler, Angew. Chem., Int. Ed., 2004, 43, 6686.

20 P. B. Hitchcock, J. Hu, M. F. Lappert and J. R. Severn, Dalton Trans., 2004, 4193.

21 M. C. Kuchta and G. Parkin, Coord. Chem. Rev., 1998, 176, 323.

22 Y. L. Zhou and D. S. Richeson, J. Am. Chem. Soc., 1996, 118, 10850.

23 S. G. Hickey, C. Waurisch, B. Rellinghaus and A. Eychmueller, J. Am. Chem. Soc., 2008, 130, 14978.

24 P. B. Hitchcock, M. F. Lappert, L. J. M. Pierssens, A. V. Protchenko and P. G. H. Uiterweerd, Dalton Trans., 2009, 4578.
25 P. B. Hitchcock, E. Jang and M. F. Lappert, J. Chem. Soc., Dalton Trans., 1995, 3179.

26 M. Veith, O. Recktenwald and E. Humpfer, Z. Naturforsch., B: Chem. Sci., 1978, 33, 14.

27 M. Veith, M. Notzel, L. Stahl and V. Huch, Z. Anorg. Allg. Chem., 1994, 620, 1264.

28 S. M. Mansell, C. A. Russell and D. F. Wass, Inorg. Chem., 2008, 47, 11367.

29 J. P. H. Charmant, M. F. Haddow, E. Hahn, D. Heitmann, R. Fröhlich, S. M. Mansell, C. A. Russell and D. F. Wass, Dalton Trans., 2008, 6055.

30 T. Gans-Eichler, D. Gudat and M. Nieger, Angew. Chem., Int. Ed., 2002, 41, 1888.

31 T. Gans-Eichler, D. Gudat, K. Nattinen and M. Nieger, Chem. - Eur. J., 2006, 12, 1162.

32 S. M. Mansell, R. H. Herber, I. Nowik, D. H. Ross, C. A. Russell and D. F. Wass, Inorg. Chem., 2011, 50, 2252.

33 A. D. Dilman and S. L. Ioffe, Chem. Rev., 2003, 103, 733.

34 G. A. Lawrance, Chem. Rev., 1986, 86, 17.

35 J. Beckmann, Appl. Organomet. Chem., 2005, 19, 494.

36 H. Nakazawa, M. Kishishita, T. Ishiyama, T. Mizuta and K. Miyoshi, J. Organomet. Chem., 2001, 617, 453.

37 H. V. R. Dias and W. C. Jin, Inorg. Chem., 2000, 39, 815.

38 Y. Q. Ding, H. W. Roesky, M. Noltemeyer, H. G. Schmidt and P. P. Power, Organometallics, 2001, 20, 1190.

39 A. E. Ayers and H. V. R. Dias, Inorg. Chem., 2002, 41, 3259.

40 P. B. Hitchcock, M. F. Lappert, G. A. Lawless, G. M. de Lima and L. J. M. Pierssens, J. Organomet. Chem., 2000, 601, 142.

41 M. Veith, B. W. Royan and V. Huch, Phosphorus, Sulfur Silicon Relat. Elem., 1993, 79, 25.

42 O. Hiemisch, D. Henschel, P. G. Jones and A. Blaschette, Z. Anorg. Allg. Chem., 1997, 623, 147.

43 D. A. Evans, D. W. C. MacMillan and K. R. Campos, J. Am. Chem. Soc., 1997, 119, 10859.

44 M. Westerhausen and W. Schwarz, Main Group Met. Chem., 1997, 20, 351.

45 A. Bartole-Scott, R. Resendes, F. Jakle, A. J. Lough and I. Manners, Organometallics, 2004, 23, 6116.

46 A. Asadi, A. G. Avent, C. Eaborn, M. S. Hill, P. B. Hitchcock, M. M. Meehan and J. D. Smith, Organometallics, 2002, 21, 2183.

47 A. W. Addison, T. N. Rao, J. Reedijk, J. Vanrijn and G. C. Verschoor, J. Chem. Soc., Dalton Trans., 1984, 1349.

48 SMART diffractometer control software, Bruker Analytical X-ray Instruments Inc., Madison, WI, 1998.

49 SAINT integration software, Siemens Analytical X-ray Instruments Inc., Madison, WI, 1994.

50 G. M. Sheldrick, SADABS: A program for absorption correction with the Siemens SMART system, University of Göttingen, Germany, 1996.

51 G. M. Sheldrick, Acta Crystallogr., Sect. A: Found. Crystallogr., 2008, 64, 112.

52 E. Prince, International Tables for Crystallography, Mathematical, Physical and Chemical Tables, Wiley, 2004, vol. C. 